\title{
Invasive Plant Management Plan for the Oak Ridge Reservation
}

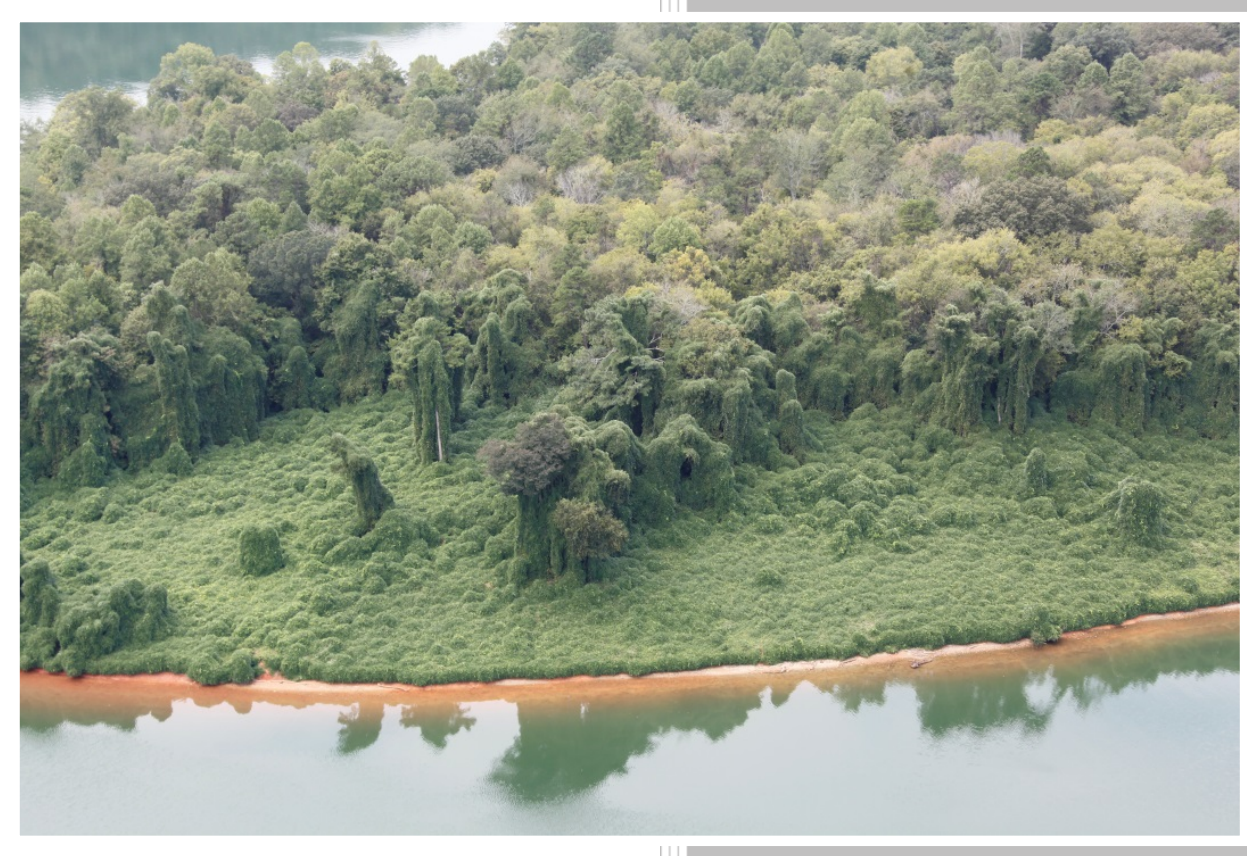

Approved for public release. Distribution is unlimited.

M. K. McCracken

N. R. Giffen

August 2017 


\title{
DOCUMENT AVAILABILITY
}

Reports produced after January 1, 1996, are generally available free via US Department of Energy (DOE) SciTech Connect.

Website http://www.osti.gov/scitech/

Reports produced before January 1, 1996, may be purchased by members of the public from the following source:

\author{
National Technical Information Service \\ 5285 Port Royal Road \\ Springfield, VA 22161 \\ Telephone 703-605-6000 (1-800-553-6847) \\ TDD 703-487-4639 \\ Fax 703-605-6900 \\ E-mail info@ntis.gov \\ Website http://www.ntis.gov/help/ordermethods.aspx
}

Reports are available to DOE employees, DOE contractors, Energy Technology Data Exchange representatives, and International Nuclear Information System representatives from the following source:

Office of Scientific and Technical Information

PO Box 62

Oak Ridge, TN 37831

Telephone 865-576-8401

Fax 865-576-5728

E-mail reports@osti.gov

Website http://www.osti.gov/contact.html

This report was prepared as an account of work sponsored by an agency of the United States Government. Neither the United States Government nor any agency thereof, nor any of their employees, makes any warranty, express or implied, or assumes any legal liability or responsibility for the accuracy, completeness, or usefulness of any information, apparatus, product, or process disclosed, or represents that its use would not infringe privately owned rights. Reference herein to any specific commercial product, process, or service by trade name, trademark, manufacturer, or otherwise, does not necessarily constitute or imply its endorsement, recommendation, or favoring by the United States Government or any agency thereof. The views and opinions of authors expressed herein do not necessarily state or reflect those of the United States Government or any agency thereof. 
Environmental Science Division

\section{INVASIVE PLANT MANAGEMENT PLAN FOR THE OAK RIDGE RESERVATION}

M. K. McCracken

N. R. Giffen

Date Published: September 2017

Prepared for

US Department of Energy

Office of Science

Prepared by

OAK RIDGE NATIONAL LABORATORY

Oak Ridge, TN 37831-6283

managed by

UT-BATTELLE, LLC

for the

US DEPARTMENT OF ENERGY

under contract DE-AC05-00OR22725 



\section{CONTENTS}

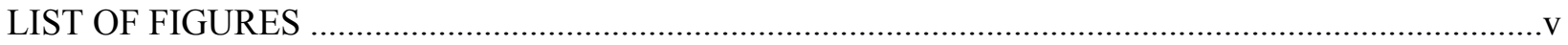

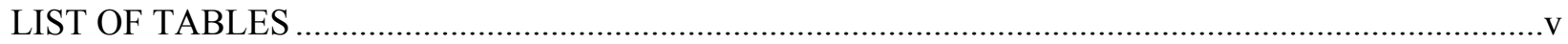

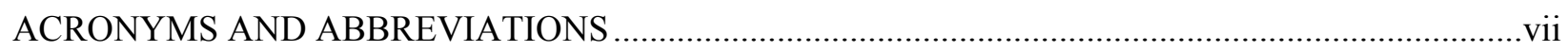

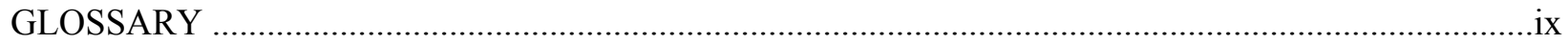

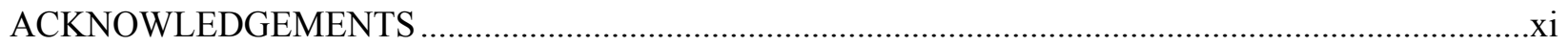

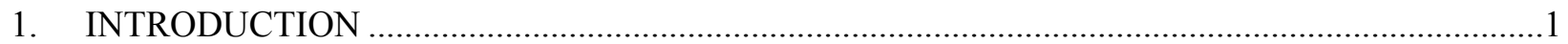

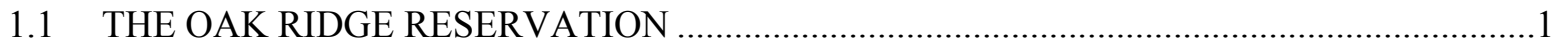

1.2 NATIONAL AND STATE PERSPECTIVE ON INVASIVE PLANTS ..................................2

1.3 ORR INVASIVE PLANT MANAGEMENT PLAN IMPLEMENTATION ............................2

1.4 PRIORITIES FOR INVASIVE PLANT MANAGEMENT ...................................................

2. REQUIREMENTS FOR MANAGING INVASIVE PLANTS ...............................................

2.1 MANAGEMENT OF UNDESIRABLE PLANT SPECIES ON DOE SITES .........................5

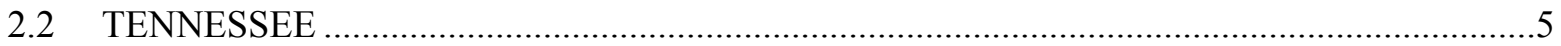

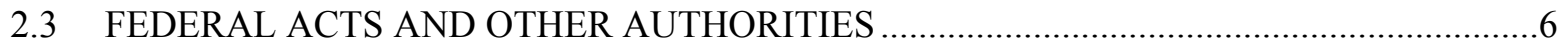

3. THE PROBLEM OF INVASIVE PLANTS ON THE ORR …...................................................

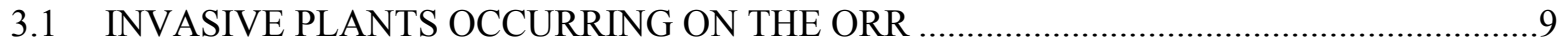

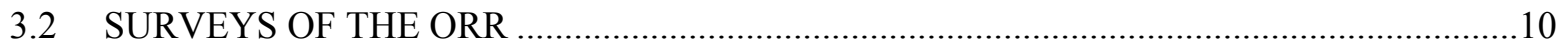

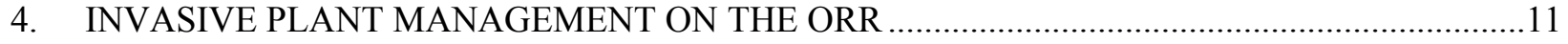

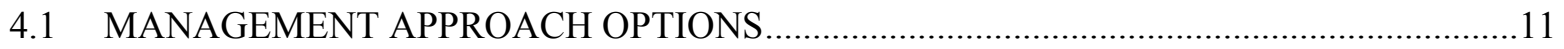

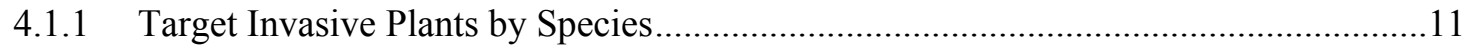

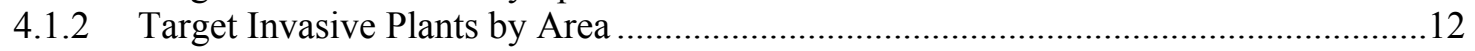

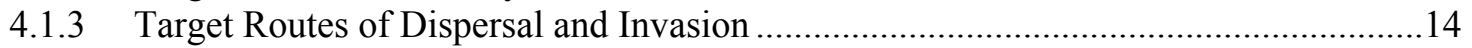

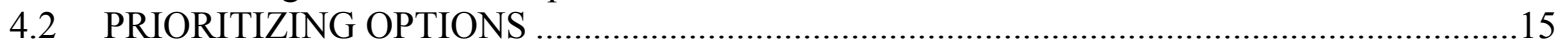

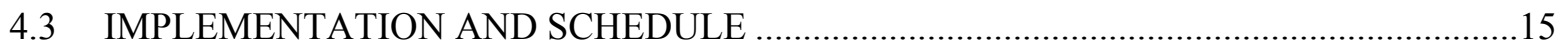

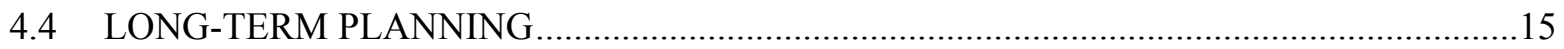

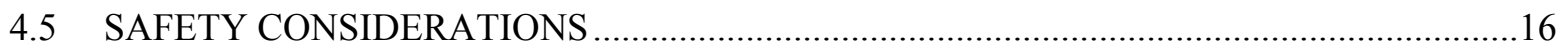

4.6 GUIDELINES TO PREVENT OR MINIMIZE THE SPREAD OF INVASIVES .................16

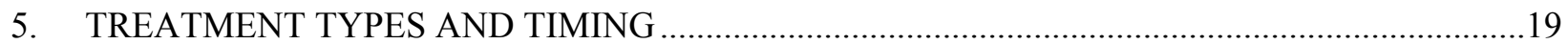

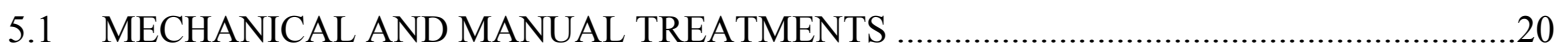

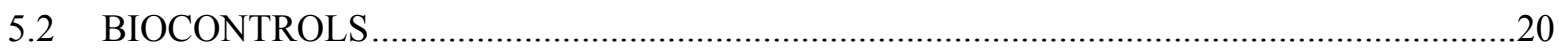

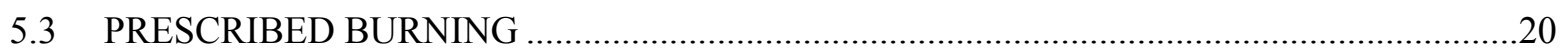

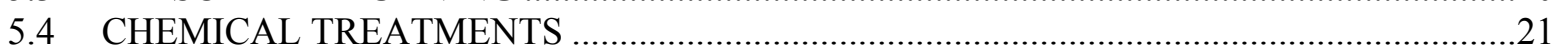

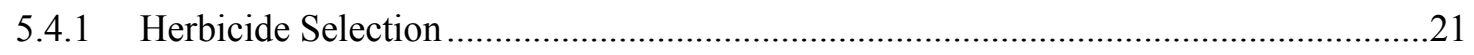

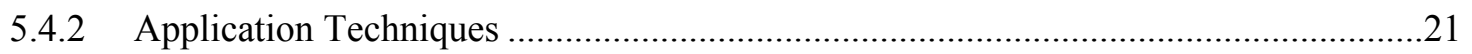

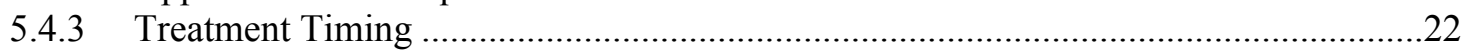

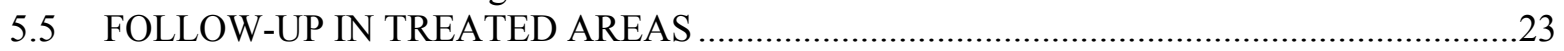

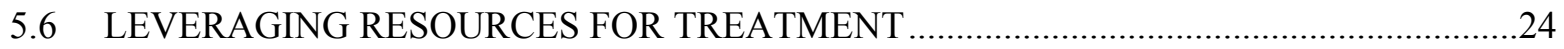

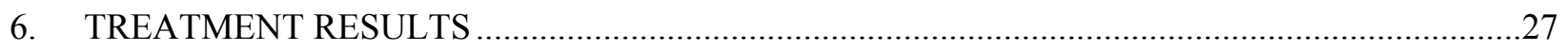

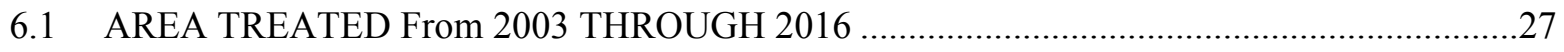

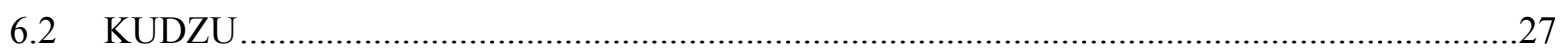

6.3 TREATMENTS TARGETING OTHER SINGLE SPECIES …...........................................29

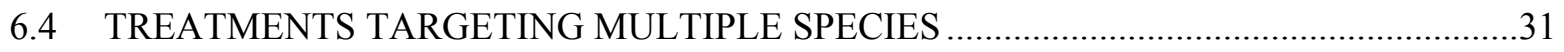

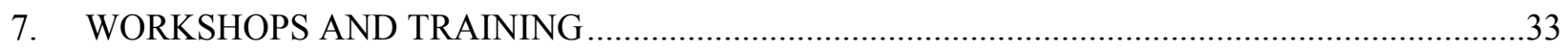

8. PLANNED INVASIVE PLANT MANAGEMENT ACTIVITIES FISCAL YEARS 2017

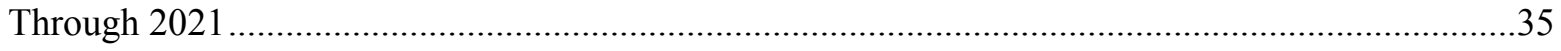

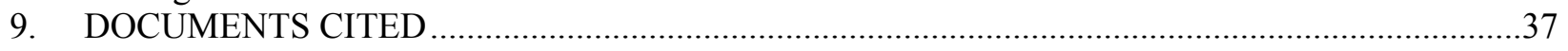

APPENDIX A: OAK RIDGE RESERVATION NON-NATIVE AGGRESSIVE PLANT SPECIES LIST. 
APPENDIX B: SELECTED PORTIONS OF EXECUTIVE ORDER 13112 AND EXECUTIVE ORDER 13751 ...1 APPENDIX C: ANNUAL TREATMENT SUMMARIES FOR ALL MANAGEMENT APPROACHES 


\section{LIST OF FIGURES}

Figure 1. Location of major routes of dispersal for invasive plants on the ORR. 14

Figure 2. Map of the Oak Ridge Reservation with invasive treatment areas indicated.

\section{LIST OF TABLES}

Table 1. Tennessee pest plants ${ }^{a}$. 6

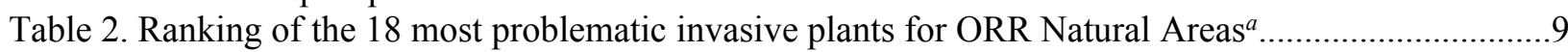

Table 3. General application techniques for using chemicals to control invasive plants on the ORR ...

Table 4. Timing of herbicide application techniques for invasive plants on the ORR .23

Table 5. Acreages treated for invasive plants on the ORR from 2003 through 2016 in various treatment categories 



\section{ACRONYMS AND ABBREVIATIONS}

\begin{tabular}{|c|c|}
\hline APHIS & Animal and Plant Health Inspection Service \\
\hline ATU & all-terrain utility vehicle \\
\hline CSC & Certified Services Company \\
\hline $\mathrm{CX}$ & categorical exclusion \\
\hline DOE & US Department of Energy \\
\hline EDDMapS & Early Detection and Distribution Mapping System \\
\hline EMS & environmental management system \\
\hline EO & executive order \\
\hline ESD & Environmental Sciences Division (ORNL) \\
\hline EPA & US Environmental Protection Agency \\
\hline ETTP & East Tennessee Technology Park (formerly K-25 Gaseous Diffusion Plant) \\
\hline FICMNEW & Federal Interagency Committee for the Management of Noxious and Exotic Weeds \\
\hline $\mathrm{F} \& \mathrm{O}$ & Facilities and Operations Directorate (ORNL) \\
\hline FY & fiscal year \\
\hline GPS & global positioning system \\
\hline ha & hectare \\
\hline IPC & Invasive Plant Control, Inc. \\
\hline IPM & integrated pest management \\
\hline MOA & memorandum of agreement \\
\hline MOU & memorandum of understanding \\
\hline NA & Natural Area (in Research Park) \\
\hline NEPA & National Environmental Policy Act \\
\hline ORNL & Oak Ridge National Laboratory \\
\hline ORR & Oak Ridge Reservation \\
\hline PS & Progressive Solutions, LLC \\
\hline PVC & polyvinyl chloride \\
\hline RA & Reference Area (in Research Park) \\
\hline ROW & right-of-way \\
\hline RSS & research safety summary \\
\hline TCWP & Tennessee Citizens for Wilderness Planning \\
\hline TDA & Tennessee Department of Agriculture \\
\hline TDEC & Tennessee Department of Environment and Conservation \\
\hline TN-EPPC/TN-IPC & Tennessee Exotic Pest Plant Council/Tennessee Invasive Plant Council \\
\hline TVA & Tennessee Valley Authority \\
\hline TWRA & Tennessee Wildlife Resources Agency \\
\hline USDA & US Department of Agriculture \\
\hline USGS & US Geological Survey \\
\hline UTK & University of Tennessee, Knoxville \\
\hline Y-12 & Y-12 National Security Complex \\
\hline
\end{tabular}





\section{GLOSSARY}

Aggressive species are those that spread rapidly, persist, and have the greatest tendency to exclude native plant species, thus, becoming pests.

Alien species means, with respect to a particular ecosystem, any species, including its seeds, eggs, spores, or other biological material capable of propagating that species, that is not native to that ecosystem [From EO 13112, Section 1. Definitions (a)].

Biocontrol or "Biological control," involves reconnecting invasive plants with the specialized natural enemies that usually limit their density in their native ranges.

Integrated pest management (IPM) is the coordinated use of pest and environmental information with available pest control methods to prevent unacceptable levels of pest damage by the most economical means and with the least possible hazard to people, property, and the environment. IPM is a sustainable approach to managing pests by combining biological, cultural, physical, and chemical tools in a way that minimizes economic, health, and environmental risks [From FIFRA, 7 U.S.C. 136r-1].

Invasive plant species means an alien species whose introduction does, or is likely to, cause economic or environmental harm or harm to human health [From EO 13112, Section 1. Definitions (f)].

Native (or indigenous) species is one that was not introduced into a geographical area by human actions.

Non-native (or alien, exotic, foreign, introduced, or non-indigenous) species is one that occurs artificially in locations beyond its known historical natural range. Non-native can refer to species brought in from other continents, regions, ecosystems, and even other habitats.

Noxious weed is a species that is, or is liable to be, troublesome, aggressive, intrusive, detrimental, or destructive to agriculture, silviculture, or important native species, public roads or other property; and is difficult to control or eradicate [From WAPA 1999]. The term "noxious weed" means any plant or plant product that can directly or indirectly injure or cause damage to crops (including nursery stock or plant products), livestock, poultry, or other interests of agriculture, irrigation, navigation, the natural resources of the United States, the public health, or the environment [From Title IV-Plant Protection Act. Public Law 106-224. June 20, 2000. Sec. 403. Definitions (10)].

Pest plants are plant species, and parts thereof that might be used for propagation, which are injurious to the agricultural, horticultural, silvicultural, or other interests of the state [of Tennessee] [From Rules of the Tennessee Department of Agriculture, Division of Plant Industries. Chapter 0080-6-24, "Pest Plant Regulations," 0080-6-24-.01. Definitions (1)].

Problematic species are those most likely to interfere with native species in natural areas.

Restoration is the return of an ecosystem to a close approximation of its presumed condition prior to disturbance.

Undesirable plant species means plant species that are classified as undesirable, noxious, harmful, exotic, injurious, or poisonous, pursuant to state or federal law. Species listed as endangered by the Endangered Species Act of 1973 (16 U.S.C. 1531 et seq.) shall not be designated as undesirable plants under this section and shall not include plants indigenous to an area where control measures are to be taken under this section [From Federal Noxious Weed Act, Sec. 2814. "Management of undesirable plants on Federal lands," (e). Definitions (7)]. 



\section{ACKNOWLEDGEMENTS}

Many individuals contributed to earlier versions of this document and to this update/revision. Their input is much appreciated. Those who were involved include staff from Oak Ridge National Laboratory (ORNL); Y-12 National Security Complex; East Tennessee Technology Park; US Department of Energy; Invasive Plant Control, Inc.; Certified Services Company; Tennessee Valley Authority; Tennessee Wildlife Resources Agency; University of Tennessee, Knoxville; and the Tennessee Department of Environment and Conservation.

Thank you to Greg Byrd (ORNL), Larry Pounds, Jim Evans (TWRA), Aubrey Deck (TWRA), Neil Giffen (ORNL), Jamie Herold (ORNL), and Bill Johnston for field reconnaissance and locating invasive infestations. ORNL staff member Tracy Clem provided invaluable work on the production of the report.

Finally, thanks to Pat Parr, Harry Quarles, Marti Salk, and Mike Ryon, retired ORNL staff members who led the establishment of invasive plant management on the Oak Ridge Reservation. 



\section{INTRODUCTION}

Invasive non-native plant species have become one of the greatest ecological threats across the country and around the world. Actively managing incursions of invasive plants is crucial to maintaining ecosystems, protecting natural resources, and ensuring proper function of facilities and their support infrastructures, power lines and other utility rights-of-way (ROWs), communications structures, roadways, and waterways. Invasive plants can threaten cultural resources, public and private properties, forests, wetlands, and other natural areas through increased risks of fire and storm damage, as well as decrease native plant diversity, particularly disrupting vital habitats of threatened and endangered species, both plant and animal.

In 2000, the Federal Plant Protection Act came into effect. Under this Act, federal agencies are required to develop and coordinate an undesirable plants management program for control of invasive plants on federal lands under each agency's respective jurisdiction. The agency must adequately fund the undesirable plants management program using an Integrated Pest Management Plan. Additionally, each agency is required to implement cooperative agreements with local and state agencies, as well as other federal agencies, to manage undesirable plants on federal lands under the agency's jurisdiction.

The US Department of Energy (DOE) takes its responsibility for addressing invasive and undesirable plant issues very seriously. Many DOE sites have programs to control invasive pest plant species. DOE has taken a proactive stance toward invasive plant control, and the Invasive Plant Management Plancreated to meet regulatory requirements of federal laws, executive orders, presidential memos, contracts, and agreements on DOE's Oak Ridge Reservation (ORR) — has been in effect since 2004. This document represents the second revision of this plan.

\subsection{THE OAK RIDGE RESERVATION}

The DOE ORR is an approximately 32,671-acre tract of land located in East Tennessee, and it is the largest continuous undeveloped area within the Ridge and Valley Physiographic Province of the Eastern Unites States. It is composed mostly of deciduous forest with large blocks of mature interior forest, extensive areas of undisturbed wetlands, open water, riparian vegetation, and several hundred acres of grassland communities. Three developed facilities are surrounded by approximately 25,000 acres of fairly unfragmented, undeveloped land. These facilities are the Oak Ridge National Laboratory (ORNL), East Tennessee Technology Park (ETTP), and the Y-12 National Nuclear Security Complex (Y-12). Most of the undeveloped area is within the DOE Oak Ridge National Environmental Research Park. Numerous DOE contractors have responsibilities for land management of various portions of the ORR. Multiple land uses for the DOE mission exist, including security, research and education; utility ROWs; fire protection access roads; grounds maintenance; protection of rare plants, animals, and special rare habitats; general wildlife management; preservation of cultural resources; cleanup and remediation of contaminated areas; new facility construction; and environmental regulatory monitoring activities. This myriad of land uses and contractors introduces challenges for effectively preventing and managing invasive species.

Plant communities on the ORR are generally characteristic of the intermountain regions of Appalachia. Oak-hickory (Quercus-Carya) forest, which is most widely distributed on ridges and dry slopes, is the dominant plant association. Minor areas of other hardwood forest types include northern hardwoods, a few small natural stands of hemlock (Tsuga Canadensis) or white pine (Pinus strobus), and floodplain forests (Mann et al. 1966). Other ecological communities found within the framework of the mixed hardwood and pine forests on the reservation include cedar barrens, river bluffs, and wetlands.

Invasive plants have spread out across the ORR from old home-site plantings, well-intentioned erosion control efforts, and wildlife forage enhancement projects. Also, severe outbreaks of the southern pine 
beetle in the 1990s have opened up large areas (about 12,000 acres) of pine plantation to potential infestation by non-native invasive plant species. Although a small portion of this damaged area was replanted with native grasses, forbs, and woody plants, most of it naturally regenerated, resulting in the growth of not only native plants, but also invasive species. Currently, an infestation of emerald ash borer, an invasive insect pest, is causing the death of ash trees (Fraxinus spp.). The loss of these trees will result in pocket openings throughout the forested areas which may become more susceptible to invasion by exotic pest plants.

\subsection{NATIONAL AND STATE PERSPECTIVE ON INVASIVE PLANTS}

Government agencies (e.g., Department of Transportation, Bureau of Land Management) began to import non-native invasive plants in the 1950s for various reasons, including erosion control along highways and public beaches. Many species were also introduced by individuals, either intentionally (e.g., gypsy moth for silk production) or accidentally (e.g., brought to this country by animals or with other imported goods). Initially there was no consideration of the potential negative effects of invasive exotic plants on ORR natural areas (e.g., ORR habitats with rare plants or wildlife), and seemingly harmless plants such as kudzu (Pueraria montana), spotted knotweed (Centaurea maculosa), and Amur bush honeysuckle (Lonicera maackii) began a silent biological invasion.

At least 4,200 species of introduced plants (about $8.4 \%$ of total introductions) have escaped from cultivation and established populations in the United States since the beginning of European colonization. Of that total, at least 675 species (15\% of introduced species) are harmful, causing severe habitat alteration and economic loss. In economic terms 79 species, or $12 \%$ of the total harmful species, caused documented losses of \$97 billion from 1906 to 1991, according to Dr. Randy Westbrooks, Invasive Plant Coordinator for the US Geological Survey (USGS). The Weed Science Society of America's January 2010 revision of its Composite List of Weeds includes 3,488 plant species as weeds in the United States and Canada. These numbers do not include the hundreds of new species that have become established in the United States in recent decades (Westbrooks 1998).

The Tennessee Invasive Plant Council (TN-IPC, formerly Tennessee Exotic Pest Plant Council, TNEPPC) published a list — with input from field biologists and land managers across the state - that includes 86 species considered invasive exotic pest plants in Tennessee (TN EPPC 2009). Of these species, 63 are considered severe or significant threats to natural communities. The alert list $-\mathrm{a}$ list of species that are problems in surrounding states but not yet known to be a problem in Tennessee-includes an additional 49 species. Appendix A contains the TN-IPC-listed invasive plants found on the ORR and describes the criteria for each invasiveness category. An updated TN-IPC list is scheduled for publication in 2018.

\subsection{ORR INVASIVE PLANT MANAGEMENT PLAN IMPLEMENTATION}

The initial Invasive Plant Management Plan for the ORR (Parr, et al. 2004) was developed to evaluate the problem of invasive plants on the ORR and their impacts on facility operations and natural areas, and to create a program to address these problems as required by EO 13112 on invasive species. This plan and its subsequent revision (Quarles, et al. 2011) address the following objectives through an ongoing evaluation process:

- identify federal, state, and local mandates which require management of invasive plants;

- determine what invasive plants occur on the ORR and the extent to which each occurs;

- prioritize specific types of areas for invasive plant management; 
- select appropriate treatments and timing;

- integrate invasive plant treatment and removal with other tasks;

- restore treated areas, as needed;

- maintain an information database;

- emphasize safety and health considerations;

- evaluate treatment results and adapt the approach, as needed, and

- increase awareness of ORR invasive plants through education of staff and the general public.

It should be noted that, as part of the management plan, a National Environmental Policy Act (NEPA) review was conducted by ORNL staff in 2003. The areas in which treatment could be conducted - along with possible impacts - were evaluated, and it was determined that the plan fell within two DOE categorical exclusions (CXs) - B 1.20 and B 3.3 (DOE's NEPA implementing procedures, 10 Code of Federal Regulations 1021, Appendix B to Subpart D). This determination is reviewed every year as required in the ORNL Research Hazard Analysis and Control System update of the ESD Field Removal or Control of Exotic Invasive Plants on the Oak Ridge Reservation Research Safety Summary (ORNL RSS 583). Based on the most recent analysis, the CX is still valid.

\subsection{PRIORITIES FOR INVASIVE PLANT MANAGEMENT}

In developing the Invasive Plant Management Plan for the ORR, a number of priorities for managing invasive plants have been identified by DOE and its contractors and subcontractors. These priorities included:

- detecting invasive plants early to facilitate their removal before they become a problem, also known as Early Detection, Rapid Response (EDRR);

- integrating invasive plant treatment and removal with other tasks;

- considering the potential for contaminant transport during treatment;

- protecting

- natural areas (e.g., rare species, special habitats),

- research areas,

- wildlife habitat,

- cultural resources,

- boundary areas,

- wetlands,

- soil stabilization/erosion control, and

- areas of potential hydrologic regime impacts;

- $\quad$ targeting treatment of

- corridors that encourage movement of invasive species (e.g., roads, streams, fences),

- ROW infrastructure,

- restoration and remediation sites,

- compliance and monitoring sites,

- areas in which security is a concern,

- areas of high visual impact, and 
- wildfire fuel accumulation areas;

- emphasizing safety and health considerations (e.g., breeding sites for mosquitoes, overgrowth in areas that could hide hazards, imminent safety hazards that should be addressed immediately); and

- implementing the philosophy and technology of integrated pest management (IPM) to increase the effectiveness of invasive plant control while minimizing any potential risks. The IPM approach results in a dynamic analysis of the standing of each invasive plant at each location of occurrence in an ongoing cycle which allows the best pest management decisions to be made based on ecological and economic values.

These priorities form the basis for use of specific treatment plans and schedules as described in the Invasive Plant Management Plan. 


\section{REQUIREMENTS FOR MANAGING INVASIVE PLANTS}

\subsection{MANAGEMENT OF UNDESIRABLE PLANT SPECIES ON DOE SITES}

DOE has active programs at many of its sites to control problem plant species, often in cooperation with state and federal agencies (DOE 1999, 2000a, 2000b, 2001a, 2001b, 2001c, 2002a, 2002b, 2009a, 2009b, 2010a, 2010b, 2010c; WAPA 2007, 2017). These programs demonstrate DOE's commitment to the control of invasive and noxious plant species.

The regulatory requirements on which DOE sites base their programs for dealing with undesirable plants include the following:

- federal laws, EOs, and presidential memos (Section 2.3);

- land withdrawal orders;

- contracts for managing DOE sites;

- state weed-management laws;

- state noxious weed lists;

- county noxious weed-management legislation;

- county noxious weed lists; and

- compliance agreements and memorandums of understanding (MOUs).

\subsection{TENNESSEE}

Information on the most significant laws or other authorities related to undesirable plants that could be applicable to the ORR is discussed in this section.

Tennessee Plant Pest Act. The Tennessee Plant Pest Act (Tenn. Code Ann. §43-6-104 et seq.) was implemented by the Tennessee Department of Agriculture (TDA). Table 1 lists the species that have been named as pest plants under that law. TDA administers rules and regulations (Rules of TDA, Chapter 0800-06-24-.02) to prevent the introduction of pest plants into the state and to eradicate and/or suppress and control the pest plants already established. The TDA is authorized to engage in investigation, inspection, treatment, eradication, and quarantine of plant materials, facilities, and equipment as may be necessary.

Roane and Anderson Counties. The ORR straddles two Tennessee counties, Roane and Anderson. Neither one has a county list of noxious weeds.

Tennessee Invasive Plant Council. With input from experts across the state (e.g., botanists, land managers, others working with the state's natural resources), TN-IPC maintains a list of introduced plant species that are invasive or may become invasive and cause damage to native plant communities (TN EPPC 2009). Currently, TN-IPC is revamping its list of invasive plant species to a more user-friendly format, which divides the list into two categories: (1) established threats and (2) emerging threats. The council acknowledges that most introduced species are harmless. It also realizes, however, that many introduced species have the potential to spread and become ecological disasters. This list has no regulatory authority but provides useful information to help guide agencies and private landowners in making responsible decisions about plant use and management. The TN-IPC website provides information about each species on its list, including a full description, images, life history, similarity to other species, and various management recommendations. 
Table 1. Tennessee pest plants ${ }^{a}$

\begin{tabular}{ll}
\hline \multicolumn{1}{c}{ Scientific nomenclature } & \multicolumn{1}{c}{ Common name } \\
\hline Commelina benghalensis & Tropical spiderwort \\
Elaeagnus pungens & Thorny olive \\
E. umbellate & Autumn olive \\
Imperata cylindrical & Cogongrass \\
Ligustrum sinense & Chinese privet \\
L. vulgare & Common privet, European privet \\
Lonicera x bella & Bell's honeysuckle \\
L. maackii & Shrub honeysuckle, Amur honeysuckle \\
L. morrowii & Morrow's bush honeysuckle, Morrow's honeysuckle \\
Lythrum salicaria, L. virgatum, and related cultivars & Purple loosestrife \\
Rosa multiflora & Multiflora rose \\
Salvinia molesta & Giant salvinia \\
Solanum viarum & Tropical soda apple \\
\hline
\end{tabular}

${ }^{a}$ Source: Rules of TDA, Chapter 0080-06-24-.02 (accessed March 28, 2011)

\subsection{FEDERAL ACTS AND OTHER AUTHORITIES}

Information on the most significant laws or other authorities related to undesirable plants that could be applicable to DOE sites are discussed in this section.

Federal Noxious Weed Act (1974). Most of the content of the Federal Noxious Weed Act was repealed by the Plant Protection Act of 2000. Section 2814, "Management of Undesirable Plants on Federal Lands," however, was amended and remains in effect. This Act (7 U.S.C. 2814(a) mandates that each federal agency:

- designate an office or person to develop and coordinate an undesirable plants-management program for control of such plants on federal lands under the agency's jurisdiction,

- establish and adequately fund an undesirable plants-management program,

- complete and implement cooperative agreements with state agencies regarding the management of undesirable plant species on federal lands under the agency's jurisdiction, and

- establish IPM systems to control or contain undesirable plant species targeted under cooperative agreements.

Undesirable plants are defined to include, but are not limited to, noxious weeds (see glossary).

Subsection (c) allows federal agencies, as appropriate, to enter into cooperative agreements with state agencies to coordinate the management of undesirable plant species on federal lands.

Subsection (d), "Exception," states, "A Federal agency is not required under this section to carry out programs on Federal lands unless similar programs are being implemented generally on State or private lands in the same area." 
Plant Protection Act. The Plant Protection Act (2000), Title IV of the Agriculture Risk Protection Act of 2000, consolidates and modernizes all major statutes pertaining to plant protection and quarantine (e.g., Federal Noxious Weed Act, Plant Quarantine Act). See Federal Noxious Weed Act, above, for information on parts of it that remain in effect. The act permits the US Department of Agriculture's (USDA) Animal and Plant Health Inspection Service (APHIS) to address all types of weed issues, increases the maximum civil penalty for violations, and authorizes APHIS to take both emergency and extraordinary emergency actions to address incursions of noxious weeds.

\section{Memorandum of Understanding for the Establishment of a Federal Interagency Committee for the} Management of Noxious and Exotic Weeds. The Federal Interagency Committee for the Management of Noxious and Exotic Weeds (FICMNEW) was established through an MOU signed by agency leaders, including leaders of DOE, in August of 1994. FICMNEW represents an unprecedented formal partnership among 16 federal agencies with direct invasive plant management and regulatory responsibilities spanning the United States and its territories.

FICMNEW's charter directs the committee to coordinate - through the respective secretaries, assistant secretaries, and agency heads - federal agency management of these species as well as gather information regarding the identification and extent of invasion by invasive plants in the United States. FICMNEW accomplishes this coordination by developing and sharing scientific and technical information, fostering collaborative efforts among federal agencies, providing recommendations for national and regional-level management of invasive plants, and sponsoring technical/educational conferences and workshops concerning invasive plants.

During monthly open meetings, FICMNEW members discuss important national and regional invasive plant issues and share information with various public and private organizations participating with the federal sector to address invasive plant issues.

FICMNEW continues to bridge the gap between federal agency invasive plant management and scientific activities and has been a driving force behind the national emphasis on education and management of the broader invasive species threat.

EO 13112, Invasive Species. EO 13112 (1999) directs all federal agencies to address invasive species concerns and refrain from actions likely to increase invasive species problems. It defines invasive species as "any species, including its seeds, eggs, spores, or other biological material capable of propagating that species, that is not native to that ecosystem."

The EO creates an interagency National Invasive Species Council to coordinate and improve the invasive species programs of 23 federal agencies and to work closely with state and local governments and private organizations on this critical economic, environmental, and health issue. The council is co-chaired by the departments of agriculture, commerce, and interior and includes seven other federal departments and agencies.

The EO also calls for the development of a National Invasive Species Management Plan to better coordinate federal agency efforts. The plan, initially completed in January 2001 (NISC 2001), was updated in August 2008 to cover the period from 2008 through 2012 (NISC 2008). 
One product of the management plan is the National Early Warning and Rapid Response System for Invasive Plants in the United States (FICMNEW 2001), which proposes a framework of public and private partners at all levels to address new invasive plants through:

- early detection and reporting,

- identification and vouchering,

- verification,

- archiving of new records in databases,

- $\quad$ rapid assessment, and

- rapid implementation of control if plants are determined to be invasive.

The EO directs federal agencies to use all available tools in an IPM approach to manage undesirable plants on federal lands (Appendix B).

Presidential Memorandum (2014). The memorandum, "Creating a Federal Strategy to Promote the Health of Honey Bees and Other Pollinators." States that federal agencies, including DOE, shall follow pollinator-friendly best management practices for federal lands. This includes control of invasive plants, as well as increasing habitat for pollinators substantially on federal lands (PM 2014). In compliance with goals of this strategy, the Department of Energy Pollinator Protection Plan was created which includes control and removal of invasive plants as a part of restoration and establishment of habitats to promote pollinator health.

Executive Order 13751, Safeguarding the Nation from the Impacts of Invasive Species. EO 13751 (2016) reinforces the directives of EO 13112 for Federal agencies to control invasive species on federal lands and waterways (Appendix B).

DOE Order O 436.1, Departmental Sustainability (2011). This order supersedes DOE O 450.1A (2008). Management of invasive plant species has been incorporated into environmental management systems (EMS) to achieve the environmental sustainability and natural resource goals of DOE. This order meets actions of federal agencies as outlined in EO 13112 and the Presidential Memorandum (2014) to create and improve pollinator habitat. 


\section{THE PROBLEM OF INVASIVE PLANTS ON THE ORR}

The occurrence of invasive plants on the reservation has been recognized for years, especially in areas where these plants have impacted management (e.g., forestry, maintenance). Planning for invasive plant management on the ORR requires fundamental knowledge and key information to adequately assess and address the problems in the context of land management goals. This knowledge and information are derived from common elements and activities of invasive plant management and are essential for management planning.

\subsection{INVASIVE PLANTS OCCURRING ON THE ORR}

More than 1,100 vascular plant species are found on the reservation. Of the 168 non-native plant species, 54 are considered severe or significant threats (Appendix A). Based on a ranking system developed by the USGS, 18 of those species were identified as the most problematic species for ORR natural areas (Table 2) (Drake, Weltzin, and Parr 2002, 2003). The USGS ranking system uses species characterization information as well as attributes of the invaded site or community.

Ongoing field characterizations and data collections add to the list of non-native invasive species on the ORR and may result in changes in priorities. For example, identification of a small population of spotted knapweed (Centaurea maculosa) in 2009 resulted in quick development and implementation of a plan to treat the plants at that location before they spread.

Table 2. Ranking of the 18 most problematic invasive plants for ORR Natural Areas ${ }^{a}$

\begin{tabular}{cll}
\hline Rank & \multicolumn{1}{c}{ Common name } & \multicolumn{1}{c}{ Scientific name } \\
\hline 1 & Japanese grass & Microstegium vimineum \\
2 & Japanese honeysuckle & Lonicera japonica \\
3 & Chinese privet & Ligustrum sinense \\
4 & Kudzu & Pueraria Montana \\
5 & Multiflora rose & Rosa multiflora \\
6 & Lespedeza & Lespedeza cuneata \\
7 & Chinese yam & Dioscorea batatas \\
8 & Tree of heaven & Ailanthus altissima \\
9 & Field garlic & Allium vineale \\
10 & Autumn olive & Elaeagnus umbellata \\
11 & Oriental bittersweet & Celastrus orbiculatus \\
12 & Princess tree & Paulownia tomentosa \\
13 & Johnson grass & Sorghum halepense \\
14 & Periwinkle & Vinca minor \\
15 & Spearmint & Mentha spicata \\
16 & Watercress & Nasturtium officinale \\
17 & Bull thistle & Cirsium vulgare \\
18 & Crown vetch & Coronilla varia \\
\hline
\end{tabular}

${ }^{a}$ Source: Drake, Weltzin, and Parr 2002 


\subsection{SURVEYS OF THE ORR}

Surveys are carried out with the goal of detecting new invasions early to begin eradication efforts as soon as possible. The location of invasive plants can also be correlated with places where they are likely to spread. Potential dispersal routes include roadways and areas that have been disturbed (e.g., pine plantations devastated by outbreaks of southern pine beetle, as well as locations where storm damage has been extensive). Several surveys of the ORR for invasive plant species were conducted as the original Invasive Plant Management Plan was being developed and implemented.

In 2000, Sara Drake - a student at the University of Tennessee at the time - characterized invasive plants within, and adjacent to, 16 ORR Research Park Natural Areas (Drake, Weltzin, and Parr 2002). In 2002, locations of kudzu that were visible from reservation roads were recorded using global positioning system (GPS) data. A project to predict the distribution and dominance of exotic species in the Southern Appalachians, funded by the US Environmental Protection Agency's (EPA) National Center for Environmental Research, included numerous permanent plots on the ORR that provided data on invasive plants within forested areas. In 2003, the Tennessee Department of Environment and Conservation (TDEC) established invasive plant monitoring plots within an area designated for conservation easement on Black Oak Ridge. A rigorous characterization of invasive species within the Research Park Natural Areas also started in 2003 (Johnston 2003). In 2004, when the initial Invasive Plant Management Plan was finalized, abundance data were available for 18 of the approximately 90 Research Park Natural or Reference Areas and a select number of species (e.g., kudzu, oriental bittersweet).

Surveys for invasive plants are conducted annually across the ORR. Areas that have been treated for invasive plants are monitored to assess the effectiveness of the treatment and plan future maintenance treatments to keep the problem species under control. Other efforts by the Natural Resources Management Team for the ORR, including rare plant surveys, forest surveys, and wildlife management activities, add to the database of locations of invasive plant incursions. As a result of these surveys, additional invasive plant species have been identified as threats. Amur bush honeysuckle (Lonicera maackii) has become a prevalent invader of forests on the ORR, and thus has been targeted for treatment. Bradford pear (Pyrus calleryana), a popular landscaping tree, is becoming a common invader of open areas along power ROWs and roadways. It, too, is being targeted for treatment in ORR natural areas. 


\section{INVASIVE PLANT MANAGEMENT ON THE ORR}

Successful invasive plant management requires a fundamental knowledge of ecosystems and key information about each invasive plant's habitat needs and growth patterns, as well as their interactions within plant communities (e.g., species interactions), and planning for invasive plant management across the ORR is no different. This knowledge is essential for setting invasive plant management goals in a variety of locations over a multi-year period.

\subsection{MANAGEMENT APPROACH OPTIONS}

Three primary approaches to invasive plant treatments are implemented on the ORR:

1. Managing an individual species wherever it occurs

2. Managing multiple species in specific areas

3. Covering the corridors or routes of dispersal and invasion

Because of the size of the ORR and the variety of problems presented by invasive plants, the judicious application of all three techniques offers the best formula for success. The approach used depends on the likelihood for success, cost, and priority for controlling the target species or protecting the specific area. In many situations treatment of specific invasive problems requires more than one treatment approach.

\subsubsection{Target Invasive Plants by Species}

Targeted species management focuses treatment on a single invasive plant species. This can be effectively implemented in areas in which one species has crowded out other species, is just getting started, or is the only invasive species interspersed with desirable plants. The goal is to implement treatment before the species population reaches a size at which it can reproduce faster than it can reasonably be controlled.

\subsubsection{Most likely to be controlled}

Some invasive species are easier to control than others and thus merit individual attention. Trees and shrub species take longer to mature and therefore have a somewhat slower rate of invasion than vines or forbs (i.e., herbaceous flowering plants other than grasses, sedges, and rushes) that usually produce seeds within the first few growing seasons. Attacking these comparatively slower-growing species before they reach reproductive age results in a good chance for control.

Several species fall into this category on the ORR. Tree species that can become significant problems include princess tree (Paulownia tomentosa), also known as royal paulownia or empress tree; mimosa (Albizia julibrissin); tree of heaven (Ailanthus altissima); callery pear, also known as Bradford pear (Pyrus calleryana); and white poplar (Populus alba). Four species of shrubs on the ORR also take a few years to reach fruit-bearing stages and are worth targeting: autumn olive (Elaeagnus umbellata); privet (Ligustrum spp.); thorny olive (Eleagnus pungens); and bush honeysuckle (Lonicera spp.). All of these species, however, were abundant and represented by fruit-bearing individuals on the ORR before invasive plant control efforts were initiated. Therefore, they now require extensive efforts to control. 


\subsubsection{New or recurrent invasive species}

Targeting an individual species is particularly useful when the species occurs only singly or at limited locations. In fact, the best time to control an invasive plant species is when it first appears, a method that has had some success on the ORR.

Oriental bittersweet (Celastrus orbiculatus) was found in the 2003 Natural Areas survey in Natural Area 2 (NA2) and was controlled by an intensive treatment approach over the course of three years. Renewing the effort to control this species while its numbers were low was a successful strategy. Identification of a small population of spotted knapweed along Bethel Valley Road in 2009 resulted in quick development and implementation of a plan to treat the plants at that location before they spread. Other invasive species that have been observed on the ORR and promptly treated when discovered include giant reed (Arundo donax) and zebragrass (Miscanthus sinensis).

For this strategy to be useful, partial surveys of the ORR should be conducted on an annual basis so that the majority of the reservation is checked about every five years. Increased awareness of potential new invaders will make early treatment more likely. Follow-up monitoring of locations where such species have been treated will also help prevent these species from becoming significant problems.

\subsubsection{Species occurring at high densities}

Targeting an individual species can be successful when it occurs at very high densities in a few locations. By their nature, some invasive species spread slowly at first, becoming locally abundant before they become a more widespread problem. By targeting areas with high-density infestations, these species may be more efficiently controlled.

Control of two high-density species, kudzu and autumn olive, was initiated in 2003 on the ORR. Kudzu is a fast-growing vine that spreads locally by rhizomes and extended stems more often than through seed dispersal. Although quite tenacious, a control effort that is repeated for several years can produce significant reductions. In 2003 two small patches of kudzu (less than one acre each) were sprayed. Follow-up treatments, and treatments in most of the major patches of kudzu on the ORR since then, have reduced the amount of kudzu on the reservation. However, continued vigilance is needed as kudzu can grow back from any surviving root crowns.

Autumn olive also occurs at extremely high densities on the ORR, and a cooperative treatment program involving the Tennessee Valley Authority (TVA), TWRA, and ORNL was started in 2003. This treatment process has been a multiyear effort because autumn olive produces large quantities of berries that are widely spread on the ORR. Control efforts have continued since then with a notable reduction of autumn olive in the areas of highest infestation on the ORR.

Other species, such as Japanese grass (Microstegium vimineum), can also occur in very high densities. Control methods are, however, less successful on this annual species than on kudzu or autumn olive. Therefore, treatment efforts on this invasive species are not a high priority on the ORR. Treatments of Japanese grass have been undertaken only where infestations threaten to interfere with DOE missions (ORNL field research plots).

\subsubsection{Target Invasive Plants by Area}

In many cases a variety of invasive plants grows in a particular area, allowing the potential for multispecies management. However, such treatment can be labor intensive, requiring careful selection of the plants to be treated to avoid treating desired native species. Also, the ability to identify the wide range 
of possible invasive species is necessary when targeting specific plants. Different species may require treatment at different times of the year and different types of treatment (Section 6). Thus, multispecies management is not always easily implemented.

Targeting invasive species by area is also important in disturbed areas. For example, the ORR forests were overwhelmed by exploding populations of the southern pine beetle in the 1990s (Roy, Evans, and Ryon 2001). From 1993 to 2001, pine beetles impacted about 12,000 acres of the forested areas of the ORR that had a pine component. Impacts in some areas were obvious, while others were subtle or unremarkable. The devastation of this primary cover opened many of these areas to invasive plants. By treating the invasive plants in these areas, negative impacts of the pine loss could be reduced or minimized, and native plants can then revegetate. Some of these areas have been cleared and reseeded with native grasses; control of invasive species is implemented as necessary during the establishment of these native grassland communities.

\subsubsection{Environmentally sensitive areas and aesthetic resources}

A multispecies approach is often necessary to protect sensitive or special-value areas. In these cases, eliminating only the primary invasive species may not meet the goal of protecting rare species or unique habitats. Also, an effort to target multiple species at one time can be more cost effective if the method of treatment is the same for all target species.

In 2003 a multispecies treatment effort was initiated in the Raccoon Creek Barrens Reference Area. The primary invasive plant at this site was sericea lespedeza (Lespedeza cuneata), but other invasive plants were also present, including Johnson grass (Sorghum halepense), fescue, privet, multiflora rose (Rosa multiflora), bull thistle (Cirsium vulgare), and Japanese honeysuckle (Lonicera japonica). All of these species were treatable with a glyphosate-based herbicide delivered by a variety of targeted methods, so a multispecies treatment was practical and efficient. Since then multispecies treatment of a variety of invasive plants has been carried out in twenty-six designated Natural Areas, and four designated Reference Areas across the ORR.

\subsubsection{Target operational areas}

In addition to treatment efforts concentrated on sensitive and unique areas, an area approach can be taken at specific reservation facilities. Because there are several major facilities within the ORR, the responsibility for some areas is divided among managing organizations. For example, TWRA manages wildlife habitat activities for the Three Bend Scenic and Wildlife Refuge, ORNL and TWRA treat areas with invasive species, and DOE roads and grounds personnel maintain most of the fire roads. Also, the invasive plant management team works with DOE, ORNL, Y-12, and ETTP maintenance and environmental organizations to integrate control of invasive plants into their normal activities.

One useful strategy for managing invasive plants is to work with the operational organizations of these facilities to treat problems in their respective areas. If regular grounds crews are scheduled to clear or trim in an area that also contains invasive plants, with a little guidance they can achieve multiple objectives with the same effort. Further, these efforts can provide leverage (e.g., labor, supplies, follow-up treatment) to cultivate even more treatment of invasive plants. For instance, when Y-12 wanted to clear the boundary around the facility, a contractor treated the invasive species and taught the Y-12 staff how to identify and treat them. This and similar efforts have raised awareness of invasive plant problems at Y-12, resulting in regularly scheduled invasive plant treatment throughout the facility at the request of facility management. 


\subsubsection{Target Routes of Dispersal and Invasion}

The third major approach to treatment of invasive species is to attack their routes of dispersal or invasion. Most invasive plants first become established along corridors of disturbance and in areas that have open areas in canopies, allowing exposure to full sunlight. These routes of dispersal/invasion (Figure 1) include existing roads, road expansions and new roads, utility ROWs, streams and riparian buffers, and fenced perimeters. By managing invasive species along these corridors, not only are individual invasive plants eliminated, but their ability to spread further throughout the ORR is also limited.

For each type of dispersal corridor, implementation of slightly different control approaches is needed. A highly selective treatment is recommended for riparian areas to minimize loss of vegetative cover that helps control erosion and stabilize stream banks. The ROW treatments along streams pose no special difficulties except in cases where steep slopes present a problem.

For roadsides, the treatment can be broader in spectrum because the invasive plants often form a thick monoculture along the edges of a road. Treatment can also be more mechanical because roads provide easy access.

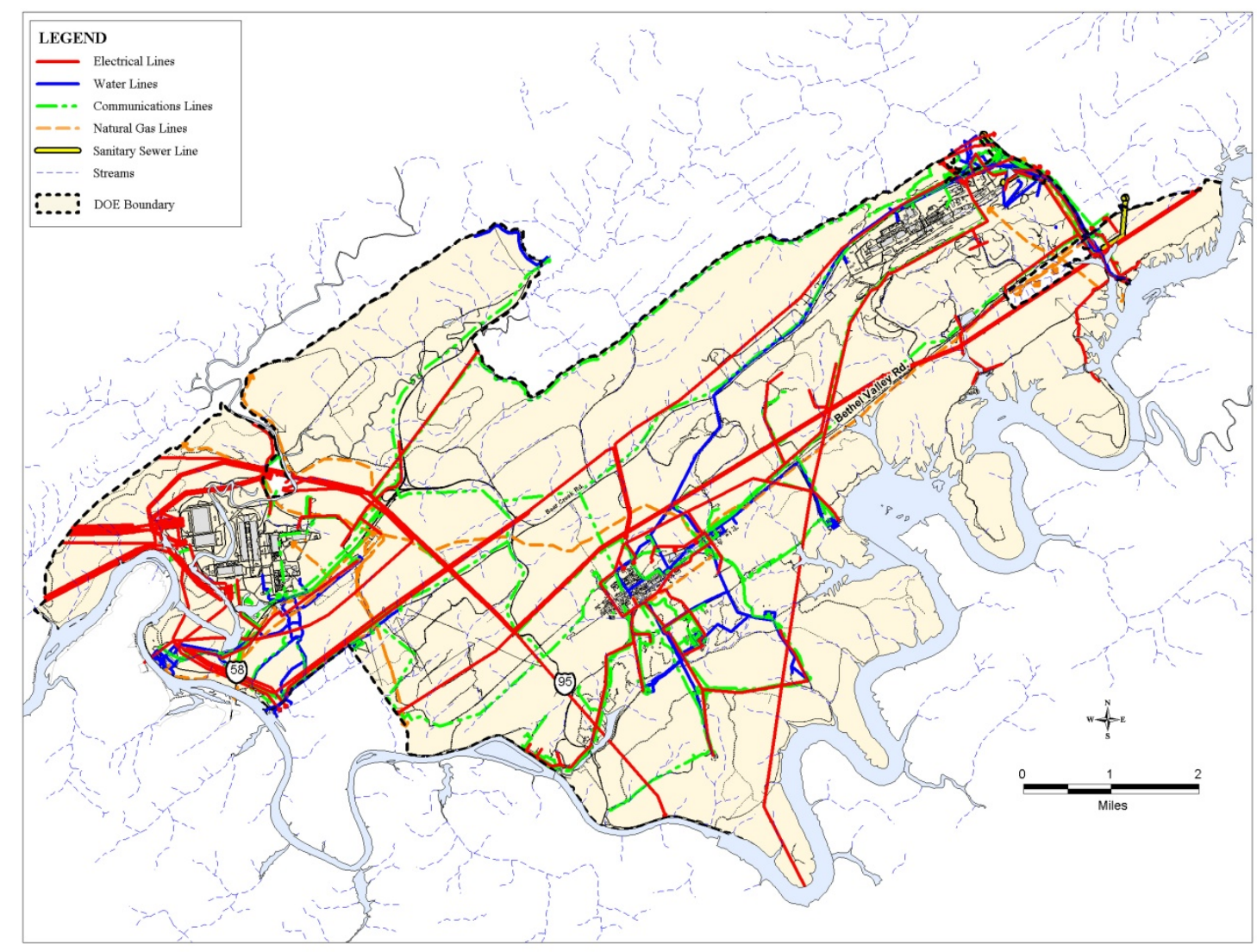

Figure 1. Location of major routes of dispersal for invasive plants on the ORR. Routes include roadways, streams, and utility ROWs. 


\subsection{PRIORITIZING OPTIONS}

The ORR is so large that available labor and funding do not allow all existing invasive species problems to be addressed at the same time. Therefore, priorities must be set when selecting locations for management of invasive plants and the specific approach to use. Prioritization involves examining the impact of specific invasive plants, selecting among the possible treatment approaches discussed above, determining applicable treatment techniques (Section 5), and identifying resources available to implement the possible treatments.

The initial Invasive Plant Management Plan included a procedure that blended all three major treatment approaches and other relevant data to provide a numerical ranking scheme to prioritize areas and species for initial treatment. As the plan has been implemented, experience gained in prioritizing treatment areas has replaced the formal quantitative ranking procedure. Priority targets for treatment are now identified by implementing an adaptive management scheme that is based on past experiences - knowing what has been done and what areas need quick follow-up. For example, there has been good success in controlling kudzu in several locations on the ORR. Thus, patches of kudzu that have been treated and are considered to be under control are scheduled to be checked each year to determine their status. Re-treating areas in which kudzu has again become a concern is given a higher priority than attempting to control kudzu in areas that have never been treated. Use of such an adaptive management scheme allows priorities to be adjusted, even on a weekly basis, as conditions change and new information becomes available. Priority rankings vary from year to year depending on progress made in controlling some species, discovery of new species on the ORR, funding changes, and availability of personnel.

\subsection{IMPLEMENTATION AND SCHEDULE}

Implementation of invasive plant management is based on an adaptive management scheme that incorporates past experiences and networking with other land managers and experts in invasive plant management. In addition, past experiences involved keeping records of what has been treated and where, as well as identifying areas for follow-up treatments, and this information adds to the breadth of knowledge used to formulate an invasive plant management strategy.

Implementation, within available funding constraints, uses contractor and subcontractor personnel who specialize in the treatment of invasive plants. Funds from the site-wide reservation management budget are leveraged with resources from the three ORR facilities and interested agencies such as TVA and TWRA. Treatment locations for which costs or labor can be shared with other groups are favored in implementation. Each year's schedule is based on the assessment of priorities, treatment options, and available funds.

\subsection{LONG-TERM PLANNING}

An overall long-term goal of reducing invasive plants as much as possible on the ORR was set during the development of the initial management plan. Implementing efforts to meet this goal has helped focus invasive plant management on the ORR. Maximum benefits have resulted from prioritizing invasive species control in areas identified as important: natural areas, research areas, security areas, wildlife management areas and remediation sites, and in areas in which treatments are most likely to make a difference.

Several strategies are employed to reach the overall long-term goal. First, a standard approach is used each year, including revisiting treated areas for evaluation and necessary follow-up control. Secondly, management of invasive plants is coordinated with other reservation management. For example, if not controlled, autumn olive would overgrow the access roads on ROWs, and there is a need to maintain low- 
growing plants on ROWs to prevent interference with power lines. Thus, maintenance of ROWs has been modified to include treatment of invasive species because the goals of the two programs complement each other. In addition, work undertaken with TWRA to convert non-native fescue areas to native grasses as part of the improvement of wildlife habitat (Ryon, Parr, and Cohen 2007) promotes the long-term invasive plant management goals.

These long-term efforts must span more than one fiscal year to be successful. Thus, consistent budget levels need to be maintained for many years.

\subsection{SAFETY CONSIDERATIONS}

An integrated safety assessment, documented in an RSS that considers all likely hazards and controls for them, is an important part of the invasive plant management program. This assessment also includes documentation of an NEPA consistency review. All activities conducted under this plan are described in RSS \# 583 (https://rhacs.ornl.gov/RSS.aspx?mode=View\&ProjectID=15122583), "ESD field-removal or control of exotic invasive plants on the Oak Ridge Reservation." The RSS addresses issues such as:

- potential hazards of a wide variety of activities (e.g., use of chemical and mechanical tools) that may be encountered when treating invasive plants;

- contamination, steep or uneven terrain, and poisonous plants or animals that may be found at sites to be treated; and

- environmental stresses (e.g., extreme heat or cold) that may occur while implementing treatments.

The RSS is required reading for all ORNL personnel participating in the invasive plant management program, and it is reviewed and updated at least annually. Each revision is reviewed by appropriate experts before it is reauthorized. In addition, all ORNL subcontracts include a safety checklist review, and contractors must demonstrate that a health and safety plan is in place within their organization that covers personnel, the environment and public.

\subsection{GUIDELINES TO PREVENT OR MINIMIZE THE SPREAD OF INVASIVES}

Preventive measures to avoid or minimize introduction and spread of invasive plants can reduce impacts to ORR resources. The following guidelines have been incorporated into routine operating activities:

- prohibit purchases or acquisition of plants identified as invasive in the eastern region of Tennessee (Appendix A) for use on the ORR, including around facilities, for remediation, or for wildlife management; special exceptions must be approved by the ORNL Natural Resources Manager or the facility Landscape Committee;

- select from a list of native plants or noninvasive species approved by DOE for use in landscaping on the ORR;

- require nurseries or agencies providing plant material to inspect and certify that their shipments do not accidentally contain plants identified as invasive in Tennessee;

- include an assessment of the potential spread of invasive plants during project NEPA reviews;

- $\quad$ purchase or acquire seed only from dealers who ensure a high degree of seed purity; 
- educate individuals who work in the field so they can identify invasive plants, spot new ones, and map locations;

- report invasive plants sighted in the field to the ORNL Natural Resources Manager or Ecosystem Management Coordinator;

- conduct annual spring and fall surveillance and monitoring to spot new invasive plants or detect new hot spots;

- $\quad$ perform road maintenance when invasive plants are less likely to be spread (i.e., before germination or prior to seed set); purchase gravel and topsoil, if needed from weed-free suppliers.

- clean tires, vehicles, and equipment carefully after they have been in an area in which invasive plants occur and seeds are likely to be carried out on the equipment;

- require a follow-up plan to deal with invasive plants after completion of field projects that may result in areas being vulnerable to the spread of invasive species; and

- continue to educate employees, reservation users, and the public (especially boundary neighbors) about invasive plants. 


\section{TREATMENT TYPES AND TIMING}

IPM, the treatment strategy used on the ORR, is an effective and environmentally sensitive approach to invasive species management that relies on a combination of commonsense practices. IPM programs use current, comprehensive information on the life cycles of invasive species and their interaction with the environment. This information, in combination with appropriate control methods, is used to manage invasive species by the most economical means and with the least possible hazard to people, property, and the environment.

However, managing exotic species does not necessarily result in complete eradication and may only accomplish control of the species for a limited time. Not only does soil often retain viable invasive plant seeds that will germinate for many years after removal of the source plants, but sites beyond the immediate management zone may also contain seeds and other dispersal propagules that can reinvade a treated area. Thus, managing problem areas on the ORR requires a long-term commitment and implementation of a plan that incorporates a monitoring program to detect recolonization, including of surrounding sites that may provide seeds and other dispersal propagules. Such a plan incorporates the need for, and enables, subsequent appropriate re-treatment.

The increase in the number of species of invasive plants in the region necessitates a regular review of the frequency and types of treatments needed for ORR infrastructure maintenance, the most effective schedule for compliance monitoring, and the best methods to use for wildland fire prevention. The types and timing of treatments make a difference in the effectiveness of the results and the efficiency of the effort. Not all invasive species will respond to the same types of treatments, and a single type of treatment may not be appropriate for a site with multiple invasive species, especially if they are interspersed with desirable plants.

To enhance the effectiveness of invasive species control, IPM takes advantage of all appropriate management options and treatment techniques, including mechanical and manual removal, biocontrol, chemical treatment, prescribed burning, and follow-up treatments.

When selecting the techniques for treatment of invasive plants on the ORR, one must consider issues such as the existence of desirable species in the area, proximity to water, stage of the plant in the growing season, density of the population, and available manpower. Land managers and researchers on the ORR continue to experiment with combinations of treatments, doses, and timing to meet site-specific needs as described in this updated Invasive Plant Management Plan.

The philosophy and technology of IPM, which has a long history in agriculture, are being applied to invasive plant problems on the ORR. Pest management as opposed to eradication implies that some pests will always be around. It is the goal of pest management to keep the pest populations down to a level at which damage is not overly evident. The IPM approach emphasizes coordinated use of information about invasive species and the local environment with available pest control methods. This will prevent unacceptable levels of pest damage by the most economical means and with the least possible hazard to people, property, and the environment. Using the IPM approach, three important concepts must be accepted:

1. No single pest control method is always used. All control options - biological, chemical, mechanical, and cultural - must be considered. Chemical control is, however, used only when needed or when most cost effective.

2. Monitoring of the pest is constantly needed to evaluate the status of a pest population (e.g., not present, present but not causing aesthetic damage, present and causing aesthetic damage). 
3. Therefore, mere presence of a pest may not be a reason to justify implementation of control actions.

Thus, the IPM integrates treatment methods with available information to increase the effectiveness of invasive plant control and minimize any potential risks.

\subsection{MECHANICAL AND MANUAL TREATMENTS}

Mechanical and manual treatments include hand pulling, weed wrenching or uprooting, cutting, and mowing, girdling and bush-hogging. Mechanical treatments (e.g., mowing) have been extensively used on the ORR, usually to meet management goals other than control of invasive vegetation (e.g., to ensure visibility along roads, to control growth of woody vegetation that could interfere with power lines). Invasive plants can also be specifically targeted with these techniques. Thickets of species such as privet and autumn olive can be bush-hogged to remove surface growth. However, the roots are typically not killed, and mowing results in additional sprouts that require repeated mowing or chemical treatment for ultimate control. Some species (e.g., tree of heaven) are stimulated by mechanical cutting and come back unless additional treatments are used. Mowing an invasive species can be part of an effective control strategy for heavy infestations if cut surfaces are also chemically treated to control root masses. Similarly, invasive trees can be individually cut, and effectiveness can be enhanced through chemical treatment to prevent root re-sprouting. Other mechanical methods, such as hand pulling and digging out roots, are also effective for control of certain species in selected settings but are labor and time intensive for large infestations.

\subsection{BIOCONTROLS}

Biological control (or biocontrol) is the science of reconnecting invasive plants with the specialized natural enemies that often limit their density in their native ranges. This process consists of surveys in the plant's area of origin to discover candidate natural enemies, studies on their biology and host specificity, and release and evaluation of their impacts on the target plant. In the eastern United States, projects have targeted aquatic, pasture, and forest weeds (Van Driesche et al. 2002). Results to date have been varied, with biocontrol showing promise for economic control of aquatic species such as Eurasian watermilfoil (Myriophyllum spicatum) (Johnson and Blossey 2002) and pasture species such as multiflora rose (Amrine 2002). Because these methods are not yet as widespread as more conventional control methods, the cost is often high. In addition, the application of biocontrol agents can be time and labor intensive. No biocontrols have been introduced on the ORR against invasive plant infestations, but when an appropriate setting for their use is found, they will be evaluated as a management option.

\subsection{PRESCRIBED BURNING}

Careful, controlled use of fire (i.e., prescribed burns) can be an effective tool for management of native grassland communities and understory vegetation in forests. The potential to use fire to control invasive species is dependent on the invasive species and whether the native vegetation is fire adapted (D'Antonio 2000; Wittenberg and Cook 2001). In some cases, fire may suppress invasive plant species, whereas in other cases fire may promote plant invasion and plant population expansion (FWS 2009).

The use of prescribed burns has been beneficial in controlling large infestations of invasive plants (Tu, Hurd, and Randall 2001). In most cases the burns are not sufficient on their own to eliminate the plants, but when they are combined with chemical pre-treatment and follow-up chemical treatment, they can be very effective. The Nature Conservancy has experimented with the use of prescribed burns and published a Fire Management Manual for use by its staff and volunteers involved in fire management operations on its behalf (TNC 2010). 
Fire has been used on the ORR to treat invasive plants, to encourage the reestablishment and growth of native grassland communities, and for removing dead vegetation such as kudzu vines. There is currently an active fire management program for native grassland communities on the ORR. Controlled burns on an as-needed basis maintain the grasslands and other special habitats by controlling a variety of woody species, including invasive plants. Prescribed burns are planned by the ORR forester, and managed by the Tennessee Division of Forestry.

\subsection{CHEMICAL TREATMENTS}

A primary goal of any invasive plant management program is selectivity - that is, control of the invasive species without harming desirable, native vegetation that is often present in close proximity. Chemical treatments can offer such selectivity through the use of appropriate application technique, timing, and chemical modes.

Chemical use is usually considered when other efforts are ineffective or when infestations must be reduced to a level where other means of control become manageable. The chemicals used for treatment are applied as recommended in conformance with product labels. These chemicals are considered safe when used according to the label recommendations. All precautions are made to minimize the impact on non-target species.

\subsubsection{Herbicide Selection}

Herbicides used for chemical treatment on the ORR include those that can be applied without certification and those that require special licensing for application. Restrictive use herbicides are only used by applicators who hold current Tennessee Certification. Selection of the appropriate herbicide depends on the chemical mode of action on a particular plant and the prevention of harm to desirable plants in the area. Information on herbicides and their appropriate uses can be obtained from TWRA, University of Tennessee Agriculture Extension Service, and the TDA. When using herbicides, it is important to follow label directions to ascertain the appropriate dilution amounts, dilution substrates, application rates, and need for personal protective clothing and/or gear. The label is the law.

\subsubsection{Application Techniques}

Techniques for applying herbicides include dabbing on cut surfaces, handheld spraying, backpack spraying, high-volume spraying from truck-mounted or trailer-mounted containers via hoses, boom sprayers, wicking devices, and basal bark treatments. Each of these techniques can be preferentially directed at specific invasive species while minimizing harm to any desirable neighbors. Table 3 describes the primary herbicide application techniques used on the ORR and includes notes about timing and selectivity. 
Table 3. General application techniques for using chemicals to control invasive plants on the ORR

\begin{tabular}{rlll}
\hline Technique & \multicolumn{1}{c}{ Description } & \multicolumn{1}{c}{ Timing } & \multicolumn{1}{c}{ Selectivity } \\
\hline Foliar spray & $\begin{array}{l}\text { Herbicide mixture is sprayed } \\
\text { on plant foliage until wet }\end{array}$ & $\begin{array}{l}\text { Whenever foliage } \\
\text { is present }\end{array}$ & $\begin{array}{l}\text { Spray can be directed to avoid desirable } \\
\text { vegetation; selective herbicides can be } \\
\text { used; application can be made to } \\
\text { evergreen foliage when deciduous } \\
\text { foliage is not present }\end{array}$ \\
Cut surface & $\begin{array}{l}\text { Herbicide mixture is sprayed, } \\
\text { painted, or dabbed onto cut } \\
\text { stumps or "frill" cuts made into } \\
\text { stems of plants }\end{array}$ & $\begin{array}{l}\text { Year-round except } \\
\text { Only target plants are treated }\end{array}$ \\
& $\begin{array}{l}\text { Herbicide mixture in oil base is } \\
\text { sprayed around stem wetting } \\
\text { the lower 12 in. (the "base," } \\
\text { hence "basal") }\end{array}$ & $\begin{array}{l}\text { Year-round except } \\
\text { when bark is } \\
\text { frozen or wet }\end{array}$ & $\begin{array}{l}\text { Spray can be directed to avoid desirable } \\
\text { vegetation when present }\end{array}$ \\
Soil surface & $\begin{array}{l}\text { Herbicide in granular form is } \\
\text { applied to the soil }\end{array}$ & Year-round & $\begin{array}{l}\text { Soil is pre-treated to prevent plant } \\
\text { growth }\end{array}$ \\
\hline
\end{tabular}

\subsubsection{Treatment Timing}

Susceptibility of plant species to chemical control depends on biological characteristics that are most often keyed to the annual growth cycle. For example, control of deciduous species with foliage-active herbicides is possible only when foliage is present and typically works best when leaves are fully developed in summer. By contrast, evergreen species offer a wider foliage treatment window. Cut surface treatments can be performed year-round on all woody species, as can basal treatments, although effectiveness varies with the season. Basal applications work best in late winter and early spring as the plant mobilizes energy to break winter dormancy.

The choice of an application technique for a specific species or group of species is limited by the period of the year when the technique can be used for that species. Next, the choice among potential techniques can be optimized based on considerations such as ease of application, opportunity for greater selectivity of application, and availability of labor and time. For example, foliage applications to evergreen species can be made when nearby, desirable deciduous species are without leaves, thereby giving an extra margin of selectivity. Basal applications can be made in winter when foot travel through a forest is easier than in summer, thereby increasing the number of stems that can be treated per unit of time. Cut surface treatments can be made for woody species whenever labor is available, regardless of the season of the year.

For the purposes of facilitating a choice of application techniques and optimizing the timing of treatments, the most problematic ORR invasive species have been grouped into eight categories based on relevant biological characteristics. These plant groups are (1) deciduous trees, (2) deciduous shrubs, (3) deciduous vines, (4) evergreen shrubs, (5) evergreen vines, (6) legumes, (7) monocots, and (8) herbaceous dicots (forbs). For each of these plant groups or species, a determination of which application techniques are possible during each month of the year has been made (Table 4). Table 4 can be used as an invasive plant control planning tool by noting seasonal overlaps of optimal treatment times. In addition, when locations of plant groups to be treated are determined and transportation to them is organized by cluster, further optimization of resources is possible. 
Table 4. Timing of herbicide application techniques for invasive plants on the ORR

\begin{tabular}{lcccccccccccc}
\hline \multicolumn{1}{c}{ Plant group } & Jan & Feb & Mar & Apr & May & Jun & Jul & Aug & Sep & Oct & Nov & Dec \\
\hline Deciduous trees & CB & CB & CB & CB & CB & $\boldsymbol{F C B}$ & $\boldsymbol{F C B}$ & $\boldsymbol{F C B}$ & $\boldsymbol{F C B}$ & $\boldsymbol{F C B}$ & CB & CB \\
Deciduous shrubs & & & & & & & & & & & & \\
$\quad$ Multiflora rose & CB & CB & $\boldsymbol{B C}$ & $\boldsymbol{B C}$ & $\boldsymbol{B F C}$ & FCB & FCB & FCB & FCB & CB & CB & CB \\
$\quad$ Autumn olive & CB & $\boldsymbol{B C}$ & $\boldsymbol{B C}$ & BC & CB & $\boldsymbol{F C B}$ & $\boldsymbol{F C B}$ & $\boldsymbol{F C B}$ & $\boldsymbol{F C B}$ & CB & CB & CB \\
$\quad$ Bush honeysuckle & CB & $\boldsymbol{B C}$ & CB & CB & CB & $\boldsymbol{F C B}$ & $\boldsymbol{F C B}$ & $\boldsymbol{F C B}$ & $\boldsymbol{F C B}$ & CB & CB & CB \\
Deciduous vines & & & & & & & & & & & & \\
$\quad$ Chinese yam & CB & CB & CB & CB & CB & $\boldsymbol{F B C}$ & $\boldsymbol{F B C}$ & $\boldsymbol{F B C}$ & FBC & CB & CB & CB \\
$\quad$ Oriental bittersweet & $\boldsymbol{C B}$ & $\boldsymbol{C B}$ & $\boldsymbol{C B}$ & $\mathrm{CB}$ & $\boldsymbol{C B}$ & FCB & FCB & FCB & FCB & CB & $\boldsymbol{C B}$ & $\boldsymbol{C B}$ \\
Evergreen shrub & FCB & FCB & $\boldsymbol{F C B}$ & FCB & $\boldsymbol{F C B}$ & FCB & FCB & FCB & FCB & FCB & $\boldsymbol{F C B}$ & $\boldsymbol{F C B}$ \\
Evergreen vine & FCB & FCB & $\boldsymbol{F C B}$ & FCB & $\boldsymbol{F C B}$ & FCB & FCB & FCB & FCB & FCB & $\boldsymbol{F C B}$ & $\boldsymbol{F C B}$ \\
Legumes & & & & & & & & & & & & \\
$\quad$ Crown vetch & & & & & & $\boldsymbol{F}$ & $\boldsymbol{F}$ & $\boldsymbol{F}$ & $\boldsymbol{F}$ & & & \\
$\quad$ Lespedeza & & & & & F & F & F & $F$ & F & & & \\
$\quad$ Kudzu & C & C & C & C & C & $\boldsymbol{F}$ & $\boldsymbol{F}$ & $\boldsymbol{F}$ & $\boldsymbol{F}$ & C & C & C \\
Monocots & & & & & & & & & & & & \\
$\quad$ Field garlic & & & & $\boldsymbol{F}$ & $\boldsymbol{F}$ & $\boldsymbol{F}$ & & & & & & \\
$\quad$ Microstegium & & & & & & & & $\boldsymbol{F}$ & $\boldsymbol{F}$ & & & \\
$\quad$ Johnsongrass & & & & & & $\boldsymbol{F}$ & $\boldsymbol{F}$ & $\boldsymbol{F}$ & $\boldsymbol{F}$ & & & \\
Herbaceous dicots & & & & F & F & F & F & F & F & & & \\
\hline
\end{tabular}

Treatment types: $\mathrm{F}=$ foliar spray; $\mathrm{C}=$ cut surface (frill or cut stump); $\mathrm{B}=$ basal bark treatment.

Abbreviations in a month indicate treatment is possible at that time with that technique; italic, bold letters indicate treatment is optimal for that type of treatment during that month with respect to ease of application, enhanced selectivity, or efficacy.

\subsection{FOLLOW-UP IN TREATED AREAS}

Managing invasive plants does not always result in their complete eradication but may only keep them under control. The ultimate goal in controlling invasive plants is the restoration of native species in an area formerly occupied by invasive species (Miller 2003). Thus, success consists of removal (i.e., killing the invasive plant with no reestablishment from existing seed stocks or nearby root stocks) followed by rehabilitation or restoration of native species (i.e., establishment and/or release of fast-growing native plants that can outcompete and outlast any surviving non-native plants while stabilizing and protecting the soil). The rehabilitation phase, which is the most important final phase of an integrated invasive plant eradication and reclamation program, can occur either naturally or with assistance (Miller 2003).

After eradication of non-native plants, native plant communities often naturally reinitiate succession from the seeds in the soil or from existing native vegetation surrounding the treated area. Native species with light seeds are usually present in the seed bank, while heavier seeds will gradually be deposited on a site by birds and other animals. When succession is naturally reinitiated, only regular monitoring and occasional spot treatments are needed as follow-up in a treated area. Thus, to ensure that this natural restoration is taking place, treated areas on the ORR are monitored for success and re-treated for invasive species as needed.

In many cases, however-especially where extensive monocultures of one invasive species have become established - more extensive efforts are required to restore native vegetation. Successful treatment of invasive species such as kudzu, which can completely occupy extensive areas, may result in open areas so large that surface erosion can become a problem before native species have time to become reestablished. Where this is the case, surface preparation, if necessary, and revegetation with native species are initiated to assist in meeting management goals. 
Valuable experience has been gained in reestablishing native species on the ORR in areas where invasive species have been controlled. For example, slopes from which kudzu has been removed have occasionally been planted with native grasses to prevent erosion problems. Powerline ROWs act as dispersal corridors for invasive species such as autumn olive, privet, and bush honeysuckle. During the demonstration phase of the Invasive Plant Management Plan, treatment was initiated on several acres heavily occupied by invasive plants within powerline ROWs and adjacent areas. The follow-up recommended was revegetation with native grasses and forbs. After initial treatment, it was determined that revegetation was not necessary as the soil was very fertile, and grasses, daylilies, and other plants grew without being planted. Some re-treatment has since been required, (e.g., for privet, which is not always killed by the initial treatment), and the powerline ROWs have been re-seeded with native grasses and forbs after herbicide treatments killed some autumn olive patches.

Native grassland communities are also being established on the ORR to replace higher-maintenance lawn areas and to restore areas affected by other stressors (e.g., the Southern pine beetle). Where such active restoration is employed, areas are monitored and maintained as necessary until native communities have become established. After native species are restored, these functional plant communities help prevent the establishment of invasive plants in what would otherwise be disturbed areas.

The initial Invasive Plant Management Plan acknowledged a concern that if plants were removed from large areas, erosion might subsequently become a problem, and revegetation might be needed to control it. However, erosion has not been a problem - even in places where large areas have been treated (e.g., for kudzu control). Additionally, extant seed banks are often capable of regenerating native plants once the overriding invasive plants are removed. Thus, very little revegetation has been necessary in areas treated for invasive species on the ORR. Erosion is still a potential concern, and areas that have been treated are monitored to make sure it has not occurred. Where erosion does occur, efforts will be implemented to control it.

\subsection{LEVERAGING RESOURCES FOR TREATMENT}

Because invasive plants are a nationwide problem, working with other agencies within the region (formally or informally) provides a mechanism to share and obtain regional resources. Agencies and organizations who have worked together on the ORR (both formally and informally) include:

- informational organizations:

- Appalachian Regional Commission,

- Environmental Landscape Design Associates,

- National Park Service (Great Smoky Mountains National Park),

- Southern Appalachian Man and the Biosphere Cooperative,

- Tennessee Citizens for Wilderness Planning (TCWP),

- University of Tennessee, Knoxville (UTK),

- GroWild (native plant nursery),

- Southeast Exotic Pest Plant Council,

- Tennessee Invasive Plant Council (TN-IPC), and

- The Nature Conservancy;

- federal and state partners:

- DOE,

- TDEC,

- TVA, 
- TWRA, and

- US Forest Service;

- managing contractors on the ORR:

- Pantex Y-12, ${ }^{1}$

- URS/CH2M OAK RIDGE,

- Bechtel Jacobs Corporation, and

- Community Reuse Organization of East Tennessee (CROET);

- invasive plant treatment subcontractors:

- Certified Services Company,

- Invasive Plant Control, Inc. (IPC),

- NaturChem, Inc., and

- Progressive Solutions, LLC.

A 2003 memorandum of agreement (MOA) among UT-Battelle, TVA, TWRA, and DOE enabled the initiation of treatment of several acres of autumn olive, privet, bush honeysuckle, and other invasive plants within powerline ROWs and adjacent areas where the plants had spread. The MOA is no longer in effect, but it was instrumental in the initiation of the invasive plants management program.

Through an agreement with DOE, TWRA, TDEC and the ORNL Natural Resource Management Team are responsible for managing wildlife on the entire ORR. Their goals to benefit wildlife include control of invasive species (plant and wildlife) and restoration using native grasses. TWRA and ORNL have cooperated in the treatment of invasive species in the Three Bends Wildlife Management Aarea and around the deer checking station on Bethel Valley Road. TWRA plans to replace fescue fields with native plants and implement forest management to the benefit of wildlife species, including the control of invasive plants.

Research has been conducted by university faculty and students on invasive plants using study sites in the Research Park. Research projects have included analyzing moisture and shading on Microstegium, evaluating the impact of invasive plants on a small population of a state-listed orchid, determining factors that may inhibit invasive plant growth, and studying impacts of changes in climate and carbon dioxide on invasive plant growth. Results of these research projects are shared through presentations at conferences and in other forums. In 2015, a University of Tennessee $\mathrm{PhD}$ candidate began a research project in which insect species diversity and abundance is compared on native versus invasive plants. Other research involving university partners is in the planning stages for 2017.

1CNS currently operates and manages the Y-12 National Security Complex. When this management plan was first developed, BWXT Y-12 operated and managed Y-12, followed by B\&W Y-12. 


\section{TREATMENT RESULTS}

Implementing this plan for invasive plants on the ORR ensures that the selection of a specific treatment (or combination of treatments) considers the likelihood for success, cost, and priority for controlling the target species or protecting the specific area. Because of the size of the ORR and the variety of problems presented by invasive plants, the judicious application of all the techniques described in Section 5 offers the best formula for success. In many situations treatment requires more than one approach.

Since the initial Invasive Plant Management Plan was prepared, much experience has been gained with respect to treatment techniques and treatment timing on the ORR. That experience has resulted in treatment strategies being refined for maximum effectiveness, as discussed below.

\subsection{AREA TREATED FROM 2003 THROUGH 2016}

Follow-up on some of the demonstration areas has continued since the original management plan was developed and implemented, and additional areas have been treated. Through the end of the 2016 treatment season), 7,000 acres had been treated. Due to re-treatment required in many places, this acreage includes significant areas treated more than once. Table 5 shows the acreages treated by year for major treatment categories (i.e., within kudzu patches, within native grass community restoration areas, along road and forest edges, in riparian zones, and within ROWs). Descriptions of much of this treatment appear below. Summaries of invasive plant treatment activities are summarized by year in Appendix C.

Table 5. Acreages treated for invasive plants on the ORR from 2003 through 2016 in various treatment categories

\begin{tabular}{ccccccc}
\hline Year & $\begin{array}{c}\text { Total acres } \\
\text { treated }\end{array}$ & Kudzu & $\begin{array}{c}\text { Native grass } \\
\text { communities }\end{array}$ & Roads/edges & Riparian & ROW \\
\hline 2003 & 98 & 12 & 12 & 47 & 2 & 23 \\
2004 & 136 & 48 & 14 & 19 & 6 & 20 \\
2005 & 125 & 56 & 15 & 38 & 11 & 0 \\
2006 & 254 & 62 & 63 & 26 & 87 & 16 \\
2007 & 236 & 58 & 70 & 96 & 12 & 0 \\
2008 & 427 & 27 & 85 & 173 & 4 & 138 \\
2009 & 526 & 35 & 30 & 14 & 5 & 0 \\
2010 & 884 & 44 & 32 & 5 & 26 & 87 \\
2011 & 806 & 63 & 32 & 10 & 17 & 165 \\
2012 & 615 & 210 & 72 & 95 & 188 & 50 \\
2013 & 329 & 78 & 28 & 179 & 4 & 0 \\
2014 & 950 & 240 & 486 & 55 & 82 & 87 \\
2015 & 629 & 249 & 103 & 52 & 158 & 67 \\
2016 & 952 & 300 & 370 & 92 & 130 & 60 \\
\hline
\end{tabular}

\subsection{KUDZU}

Kudzu, known as the weed that ate the South, is a native of Asia that has been widely planted throughout the eastern United States as a method of erosion control. Successful long-term control of kudzu requires the root crown to be destroyed (PCA 2009), any root crowns remaining can lead to re-infestation of an 
area. Mechanical methods involve cutting vines above ground level and destroying all cut material. Cutting should be followed by immediate application of a systemic herbicide (e.g., picloram) to cut stems to encourage transport of the herbicide into the root system. The USDA is searching for biological control agents for kudzu that will not impact native species (Britton, Orr, and Sun 2002; Weaver and Lyn 2007). During 2014 it was noted by Certified Services Co. that several kudzu patches on the ORR had been infested by kudzu bug (Megacopta cribraria), a natural predator of kudzu. The kudzu bug has not been shown to control kudzu, and has itself become an agricultural pest on such crops as soy beans and other legumes.

When the initial Invasive Plant Management Plan for the ORR was being developed, kudzu was found in many areas — some of them very large patches. Treatment was initiated at many kudzu patches of varying size on the ORR. Areas in which kudzu has been treated include those below. Unless otherwise mentioned, treatment consisted of spraying with a low rate of Tordon 101 (picloram) in a high volume of water.

Freels Bend: Trees at the Freels Bend entrance that were being overtaken by kudzu were treated in 2004. By 2007 only a few straggling vines needed follow-up treatment. Treatments were also conducted in 2012. A kudzu patch across Bull Bluff Road, opposite Freels Bend Road, was treated in 2014 and again 2016 and 2017 to kill straggling vines.

Scarboro Road: In the summer of 2005, kudzu covered a slope at the boundary of Y-12. In August that year the entire area was sprayed, and results were seen in September. By April 2006 grasses and forbs had replaced the vanishing kudzu. In August of 2007 the vegetation community was more diverse. In 2010 additional treatment was necessary as some kudzu had returned, then again in 2014. New kudzu growth has continued to be a problem along forested portions of Scarboro Rd. as it spreads from TVA ROWs.

Gallaher Bend: A 42-acre patch of kudzu on Gallaher Bend was contained in 2009 to prevent it from invading the surrounding forests while additional treatments were planned. Initial plans to treat the remainder in 2010 were derailed by the need to re-treat kudzu elsewhere on the ORR. Thus, in 2010 the corridor around the patch was re-treated and expanded, and plans were made to treat more of the patch in the future. After treatment in 2013 the entire area underwent a prescribed burn. Later that same year an effort was undertaken to plant white pine seedlings as well as native grass seed and a few hardwood seedlings. Kudzu remained in small patches, particularly at the Clinch River/Gallaher Bend shoreline. In 2012, 2013, 2014 and 2016, straggling vines were treated again because some regrowth of kudzu was noted, particularly around the forest bordering the previous kudzu patch.

ETTP railroad: Kudzu encroachment on the ETTP railroad spur and patrol road was a long-standing problem. Spraying just the railroad track area did not address the greater problem. When kudzu growing on trees was also sprayed, results were obvious after a little more than 2 weeks. This application was followed by spot treatments in subsequent seasons. After spraying inside the DOE boundary fence on the bluffs above the railroad, it was noted that kudzu between the DOE fence and the railroad tracks was making a rapid return. In 2016 treatment of kudzu was reinitiated, and should be continued in subsequent years.

Blair Road and Highway 58 intersection: Kudzu was among the problem invasive species at this location that had aesthetic impacts. During 2004 it was treated with a foliar spray of Garlon 3a and Tordon 101 by CSC. Spot treatments in 2005 and 2006 removed straggler kudzu. Native vegetation then reestablished itself from the existing seed bank. In 2014, 2015, and 2016 these 
areas were treated again for straggling kudzu vines and other invasive plants. It should be noted that this area is adjacent to TVA ROWs which harbor large kudzu infestations.

Bear Creek Road and Highway 95 intersection: Kudzu was among the problem invasive species at this location that had aesthetic impacts. It also threatened a plantation of walnut trees. Kudzu was treated from 2004 to 2006, and warm-season grasses were planted in 2005. By 2007 most kudzu had been removed without damaging the trees on which it was growing, and native grasses were growing. Follow-up treatment was needed to remove the large kudzu root nodes. This walnut plantation area and other corners at this intersection have been treated annually since 2011.

McKinney Ridge: Kudzu growing in this area was removed to protect nearby hemlock trees. This area has also received subsequent maintenance kudzu treatments.

Hickory Creek Bend: A large patch of kudzu encompassing the entire tip of Hickory Creek Bend at the Clinch River was spotted using helicopter surveillance in 2012. Treatment of this area began in 2013 along with treatment of other invasive plants throughout the entire peninsula. Progressive Solutions, Inc. succeeded in treating the peninsula in 2014, and a prescribed burn of the kudzu area was completed in the early spring of 2015. In the spring of 2015, bare ground patches in this location were planted with native grass seed, and in 2015 and 2017 re-treatment of straggling kudzu vines was conducted.

Experience on the ORR has shown that a high-volume spray of a low concentration of Tordon 101 can successfully reduce the level of kudzu infestations. In sensitive areas where there could be root uptake of herbicide from the soil by non-target broadleaf plant species (e.g., the walnut plantation), Roundup or Transline is used instead of Tordon 101. However, monitoring is necessary once initial treatment has been completed, as kudzu can grow back even after not being observed at treated areas for several years. For example, in the summer of 2016, visits to several treated areas on the ORR (e.g., the ETTP railroad site) revealed resurgent kudzu populations that required additional treatment.

Thus, all areas treated for kudzu will be checked at least once each growing season and additional treatment provided, as necessary.

\subsection{TREATMENTS TARGETING OTHER SINGLE SPECIES}

In addition to kudzu, several other invasive plants are persistent problems on the ORR and have therefore been individually targeted. The species - and locations where they have been treated - include those below.

Autumn olive: Autumn olive is a persistent problem on the ORR, with a particularly heavy infestation at Freels Bend, along power line ROWs, and in open fields. Removal of this invasive plant requires a combination of mechanical and herbicidal control techniques.

Chinese yam and thorny olive: Chinese yam (a.k.a. air potato) (Dioscorea batatas) and thorny olive tend to grow along the forest/field or forest/road interface on the ORR. They have been treated with targeted spraying. These treatment methods include hacking the bark and spraying herbicide into the cut surfaces, spraying around the base of the plants, and spraying the leaves of Chinese yam.

Princess tree: Princess trees are a problem at Y-12, where the seeds lodge next to buildings, germinate, and quickly grow into large-size trees. Damage to pavement also can occur when 
seeds fall into cracks and then germinate. Treatment is primarily application at cut surfaces near the base of the trees.

Purple loosestrife: Purple loosestrife (Lythrum salicaria) has become a problem invasive species on the ORR along Scarboro Creek where it rapidly replaces native vegetation. The invasive plant management team treated that area with a foliar spray of Accord (glyphosphate) in 2007. In an act that will prevent purple loosestrife from reinvading that area, spot spraying of upstream plants was organized in 2010 by TCWP with the approval of the city of Oak Ridge. Additional spot spraying was conducted by the invasive plant management team and TVA staff with assistance from TCWP volunteers. Subsequent treatments of the purple loosestrife infestation have been carried out in 2013, 2014, and 2016. In addition to foliar spray, the flowering heads of purple loosestrife are removed and bagged to eliminate the potential for seed release.

Spotted knapweed: Spotted knapweed, a plant native to eastern Europe, is a pioneer species that grows in recently disturbed sites or openings. Unfortunately, once it has been established at a site, it continues to spread into the surrounding habitat. Spotted knapweed was first found growing on the ORR in 2009 along a powerline ROW. Treatment of those plants consisted of spot spraying with a $5 \%$ solution of Garlon $3 \mathrm{a}$. When the site was checked a week later, sprayed plants were dead. Because most of the plants had not yet set seed, this treatment should help limit the spread of the infestation. Monitoring of the site takes place annually, and treatment has continued as needed, including collecting seed heads present at the time of herbicide treatment. Knapweed will also be included as a target species in invasive plant surveys of the ORR.

Microstegium: Although Microstegium is too widespread throughout the ORR to be effectively controlled with current resources, research plots within the Carbon Sequestration Research Area have been specifically targeted to prevent interference with long-term projects. Research has shown that Microstegium can be managed with a combination of early season foliar spray and growth inhibitor. This has not yet been tried on the ORR, but will be among top testing priorities in the coming years.

Chinese wisteria: A large patch of Chinese wisteria was found in the Bearden Creek area in 2012. This plant grows thickly, covering ground vegetation, and growing vertically up trees and other structures. This infestation was treated in 2013 and again in 2015. Additional large patches were found along a gas line ROW near Haul Road and TN Highway 58 in 2016. This area (Parcel ED3 ) was sold, and the new owner was advised of methods to control the Chinese wisteria infestation.

Winter creeper: Winter creeper (Euonymus fortunii) is increasing its invasiveness on the ORR and elsewhere in East Tennessee. This plant is still sold in plant nurseries, particularly big box stores, as a ground cover. On the ORR, winter creeper has heavily invaded creek banks and riparian zones and has also expanded its coverage along forest floors and even within turf grass areas. Treatment is best conducted on this evergreen plant after native plants have gone dormant for the winter. This plant is difficult to treat, as its foliage has a waxy cuticle that is not easily penetrated by herbicide. Winter creeper has been treated along White Oak Creek in mitigation revegetation areas, including the High-temperature Materials Laboratory streamside remediation area and the First Creek remediation area, but Winter creeper is an increasing problem that will be dealt with in years to come.

Thus, all areas that have been treated for these species continue to be checked at least once each growing season to determine whether additional re-treatment is necessary. 


\subsection{TREATMENTS TARGETING MULTIPLE SPECIES}

Some areas are first treated for the invasive species causing the major problems, with follow-up treatments targeting a number of other invasive plants. Targeting multiple species is more efficient and cost-effective than treating each invasive species individually. Such management is the preferred method of dealing with invasive plants on the ORR whenever possible. Some examples of situations in which this approach has been implemented (in addition to those described in Section 6.1) include those below.

Freels Bend: On Freels Bend, 442 acres have been spot treated with herbicide to control a number of species, including tree of heaven, autumn olive, bush honeysuckle, mimosa, multiflora rose, princess tree, privet, and thorny olive. The area was initially treated in 2009. Monitoring of that area in 2010 showed good control of all those species. Additional acres were spot treated in 2010, 2012, and 2014 with similar good results. In 2016, in cooperation with TWRA, over 60 acres of previously untreated mid-successional land was treated with foliar spray then bush hogged to return the area to the early successional stage and to remove all invasive plants - particularly autumn olive, privet, and multiflora rose. Goose feeding fields, which had been maintained as fescue, have been treated with herbicide to begin the process of converting these fields to native clover, grasses, and forbs as forage for Canada geese and other wildlife.

White Oak Creek Watershed: The riparian area of the White Oak Creek Watershed was covered by several species of invasive plants, including autumn olive, privet, thorny olive, winter creeper, Johnson grass, mimosa, princess tree, and porcelain berry. The high seed production plants and the creek's water flow increased the distribution of these invasive plants. Treatments began in 2003 using a variety of techniques, including backpack sprayer, truck tank sprayer, and cutsurface treatments. In the summer of 2006, 1,160 gallons of spray were applied, and 13.6 miles of the stream bank and 15.9 miles of roadside in the watershed were treated. Seven staff members worked for a combined 1,000 hours. Selected portions of the watershed have been re-treated since 2006. Targets include privet, autumn olive, Johnson grass, crown vetch, Japanese honeysuckle, and winter creeper. Efforts are ongoing in this watershed.

Y-12 security boundary: The Y-12 security boundary was treated to remove invasive plants, including tree of heaven, which is stimulated by cutting and therefore requires herbicide application. Other invasive plants that were treated included autumn olive, thorny olive, and privet. In 2014 the Y-12 boundary along Scarboro Road was treated. Portions of this area were retreated in 2016. In 2016 over 308 acres of land which had been leased to the City of Oak Ridge for use as sludge fields were returned to DOE. As part of a new effort, over 180 acres of these fields were spot treated in 2016. To begin the process of converting these and other fields to native grassland communities in order to increase the pollinator population and expand the wildlife habitat broadcast spray to kill fescue and remaining invasive plants will continue, followed by prescribed burning. Efforts in these fields will continue in subsequent years.

Wheat Community African burial ground: The graveyard was overgrown with multiple invasive species. The area was treated and is now monitored to catch invasive plants before they again become a problem.

Wheat Church (aka Jones Church) vista: After dead pines were cleared from the area between Wheat Church and the highway, brush grew up and eventually again obscured the view of the church from the road. That area then became a native grass demonstration area. Treatment included removing invasive species and prescribed burning to encourage native grass growth. The forest edges nearby were also treated. 
Many other areas of varying size are treated or re-treated annually throughout the ORR. Figure 2 gives an overall view the areas of the ORR that have been treated since the beginning of invasive plant management activities. The stable budget allows for planning of treatments in new areas where invasive plants are found and continued maintenance of many areas already treated. In 2013, 2014, and 2016 UTBattelle Facilities and Operations management provided additional funds which allowed extensive areas to be treated for invasive plants in preparation for the reestablishment of native grassland communities and riparian zones, and forest edge improvements.

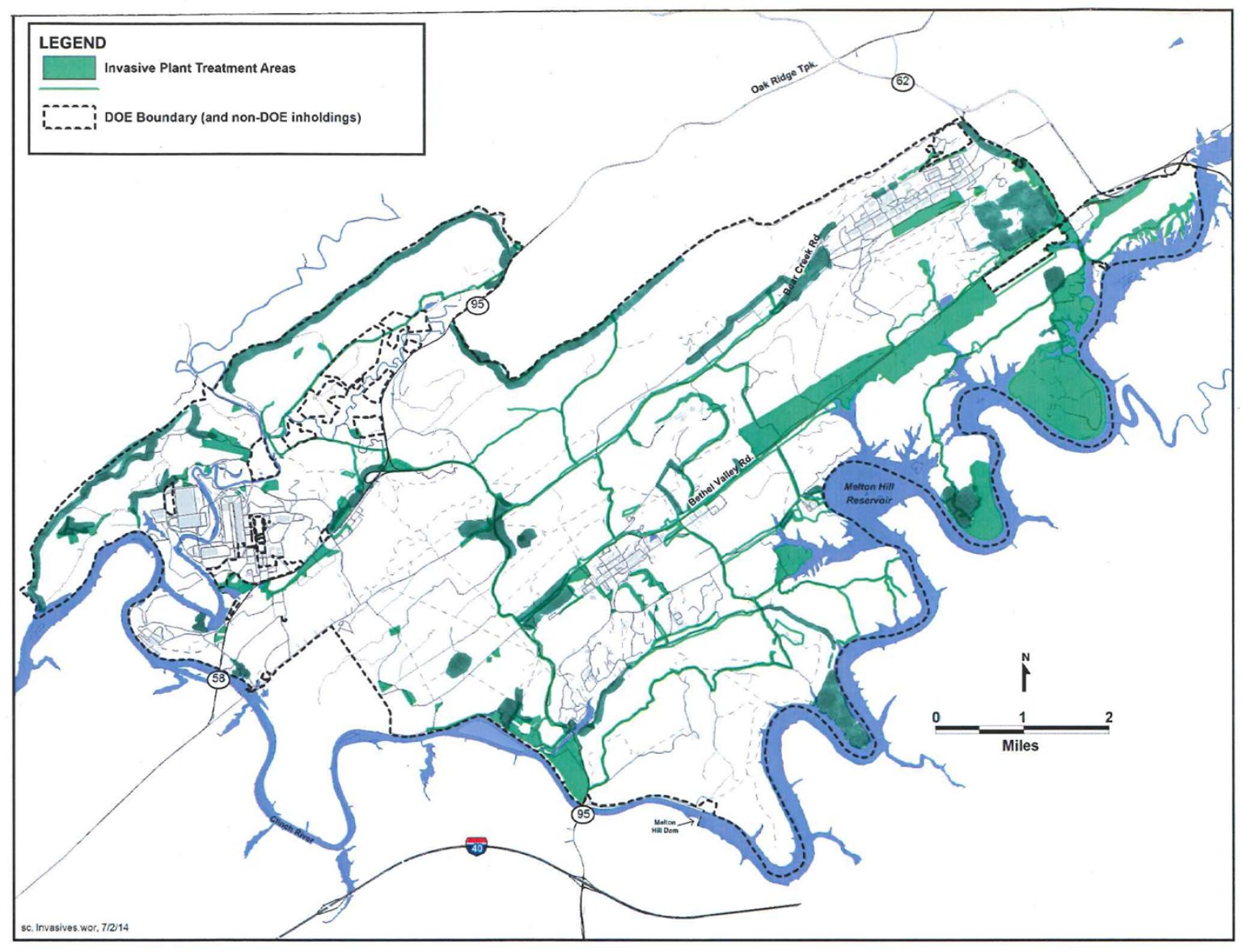

Figure 2. Map of the Oak Ridge Reservation with invasive treatment areas indicated. 


\section{WORKSHOPS AND TRAINING}

ORNL held a workshop in April of 2003 that provided information on invasive plants to individuals who make land management decisions and/or oversee such activities on the ORR. Approximately 50 individuals from 11 different agencies and organizations involved with or interested in ORR land management participated. The workshop featured a number of speakers, including Steve Manning and Lee Patrick from IPC, a company that deals with nationwide management of invasive species; Sam Rogers, a professor from UTK with expertise in invasive plants; and Mike Berkley, a nursery owner from middle Tennessee with expertise in using native plants in landscaping. Presentations at the workshop covered identification of invasive species and various treatment approaches. Site visits to several ORR field projects showcased ORNL's demonstration program on managing invasive species.

Shortly after the workshop, follow-up meetings of small groups were held at ETTP, Y-12, and ORNL to discuss needs specific to each of the facilities. In addition, invasive plant experts presented training sessions to reservation users and caretakers (e.g., maintenance staff at each site). These sessions described potential threats from invasive plants, provided information on how to identify invasive species, discussed treatment options, and generally increased awareness of the issue of invasive plants.

Another workshop was held in the City of Oak Ridge in September of 2012. Speakers at this meeting included several members of the TN-IPC, among them Belinda Ferro, a biologist with NRCS; Sharon Jean-Philippe, a professor at UTK; and Kristine Johnson, a biologist with the Great Smoky Mountains National Park; among others. This meeting concluded with breakout sessions of two discussion groups: Maintenance Staff issues and Nursery Growers issues. Talks and discussion were followed by a demonstration of field techniques for invasive plant treatment at the UT Arboretum.

Since then ORNL staff have regularly interacted with individuals at each facility to discuss site-specific issues and to interact in planning treatments. Such interaction will continue in the future and may be expanded to include other facility staff members and contractor staff who are actively involved in ORR invasive plant treatment.

In addition, ORNL staff members have made presentations to various community organizations regarding the importance of controlling invasive plants in the local environment. ORNL staff members have also provided assistance to TCWP with community invasive removal projects along Oak Ridge streams and in cedar barrens. Invasive plant control along Oak Ridge greenways located on DOE property is in progress. The DOE ORR Ecosystem Management Coordinator has spoken with several organizations regarding development of an invasive plant management plan. These organizations include the Lookout Mountain Conservancy Group in Chattanooga, TN, the Knoxville chapter of the Garden Clubs of America, and the Knoxville City Parks and Greenways managers. A workshop is being planned for October of 2017 at Ijams Park in Knoxville, TN. A brochure on invasive plant identification was created by DOE ORR Plant Ecologist Jamie Herold, and these brochures are distributed to the public at all three facilities on the ORR during events like Earth Day, City of Oak Ridge events, and other activities and events across Tennessee. The DOE ORR Ecosystem Management Coordinator serves on the boards of directors of TN-IPC, the Southeast Exotic Pest Plant Council and the National Association of Invasive Plant Council, as well as the DOE Invasive Species Workgroup, formed in 2017. 


\section{PLANNED INVASIVE PLANT MANAGEMENT ACTIVITIES FISCAL YEARS 2017 THROUGH 2021}

In fiscal years 2017 through 2021, the following activities will be undertaken:

- kudzu spraying and reclamation as necessary;

- autumn olive treatment in areas of densest infestation;

- control of invasive plants in native grassland community restoration fields;

- control of thorny olive, privet, and other invasive plants in ORR forest edge areas;

- monitoring of natural areas and reference areas, with invasive treatment as necessary;

- public invasive plants awareness walks and other educational/recreational activities;

- cooperation with the city of Oak Ridge on invasive plant prioritization and treatment on ORR boundaries and greenways;

- promoting greater interaction with TVA in managing its ROWs to control invasive plant species and limit their dispersal;

- monitoring for invasive plant species not yet sighted on the ORR but known to be spreading to the area;

- treatment of invasive plant infestations throughout ORR based on prioritization;

- exploring ways to leverage resources and share our experience via public talks, workshops and other events as well as conferences specific to land managers;

- research and promote natural control methods, native plant competition and preventative activities; and

- educate the public on invasive species and how to control them. 


\section{DOCUMENTS CITED}

Amrine, J.W. 2002. "Multiflora Rose." In Biological Control of Invasive Plants in the Eastern United States. FHTET-2002-04, 265-292. USDA Forest Service Publication, Morgantown, West Virginia.

Britton, K.O., D. Orr, and J. Sun. "Kudzu.” In Biological Control of Invasive Plants in the Eastern United States. FHTET-2002-04, 325-330. USDA Forest Service Publication, Morgantown, WV.

Chung, H. 2010. "Goats Used as Green Method for Ridding Fort Dickerson of Kudzu," knoxnews.com. Posted July 26, 2010. (http://www.knoxnews.com/news/2010/jul/26/goats-used-green-methodridding-fort-dickerson-kud/, accessed 6/7/11)

D’Antonio, C.M. 2000. “Fire, Plant Invasions, and Global Changes.” In Invasive Species in a Changing World, edited by H.A. Mooney and R.J. Hobbs, 65-94. Island Press, Washington, DC.

Department of Energy (DOE). 1999. Rocky Flats Environmental Technology Site Vegetation Management Environmental Assessment and Finding of No Significant Impact. DOE/EA-1293. DOE Rocky Flats Field Office. Golden, CO.

Department of Energy (DOE). 2000a. Bonneville Power Administration Transmission System Vegetation Management Program. Final Environmental Impact Statement. DOE/EIS-0285. Portland, OR. (http://nepa.energy.gov/finalEIS-0285.htm, accessed March 8, 2011)

Department of Energy (DOE). 2000b. Bonneville Power Administration Transmission System Vegetation Management Program. Record of Decision. DOE/EIS-0285. Portland, OR. (http://nepa.energy.gov/nepa documents/rods/2000/VEGROD.PDF, accessed March 9, 2011)

Department of Energy (DOE). 2001a. 2001 Annual Vegetation Management Plan for the Rocky Flats Environmental Technology Site. Revision 1. DOE Rocky Flats Field Office. Golden, CO.

Department of Energy (DOE). 2001b. Hanford Site Biological Resources Management Plan. DOE/RL-96-32. (http://www.pnl.gov/ecomon/docs/brmap/BRMaP.pdf, accessed March 9, 2011)

Department of Energy (DOE). 2001c. Integrated Natural Resources Management Plan, Environmental Assessment, and Finding of No Significant Impacts for Rock Creek Reserve. DOE/EA-1371. DOE Rocky Flats Field Office. Golden, CO. (http://nepa.energy.gov/ea1371.htm, accessed March 8, 2011)

Department of Energy (DOE). 2002a. Sitewide Noxious Weed Management Plan. PLN-611. Idaho National Engineering and Environmental Laboratory, Idaho Falls, ID.

Department of Energy (DOE). 2002b. "U.S. Department of Energy Management of Invasive Plant Species." Prepared by Lee Banicki (EH-41) for the 2002 North American Weed Management Association meeting.

Department of Energy (DOE). 2007. Rocky Flats Legacy Management Agreement. DOE Office of Legacy Management, March 8, 2011) . (http://www.cdphe.state.co.us/hm/rf/legacymgtagreement.pdf, accessed

Department of Energy (DOE). 2009a. 2009 Annual Ecology Report for the Rocky Flats Site. (http://www.lm.doe.gov/documents/sites/co/rocky flats/ecology2009/ecology.htm, accessed March 9, 2011)

Department of Energy (DOE). 2009b. Rocky Flats, Colorado, Site Revegetation Plan. LMS/RFS/S045130.1. DOE Office of Legacy Management (http://www.Im.doe.gov/WorkArea/linkit.aspx?LinkIdentifier=id\&ItemID=5236, accessed March 8, 2011) 
Department of Energy (DOE). 2010a. Argonne National Laboratory Site Environmental Report for Calendar Year 2009. ANL-10/02. Argonne National Laboratory, Argonne, IL. (http://www.anl.gov/Community and_Environment/Environmental_Reports/ser2009.pdf, accessed March 9, 2011)

Department of Energy (DOE). 2010b. Hanford Site Environmental Report for Calendar Year 2009. PNNL-19455. Pacific Northwest National Laboratory, Richland, WA. (http://hanfordsite.pnl.gov/envreport/2009/pnnl-19455.pdf, accessed March 9, 2011)

Department of Energy (DOE). 2010c. Idaho National Laboratory Site Environmental Report for Calendar Year 2009. DOE/ID-12082(09). Idaho National Laboratory, Idaho Falls, ID. (http://www.stoller-eser.com/Annuals/2009/ReportIndex.htm, accessed March 9, 2011)

Drake, S.J., J.F. Weltzin, and P.D. Parr. 2002. Assessment of Nonnative Invasive Plants in the DOE Oak Ridge National Environmental Research Park. ORNL/TM-2001/113. Oak Ridge National Laboratory, Oak Ridge, TN.

Drake, S.J., J.F. Weltzin, and P.D. Parr. 2003. "Assessment of Non-Native Invasive Plant Species on the United States Department of Energy Oak Ridge National Environmental Research Park." Castanea 68(1):15-30.

Federal Interagency Committee for the Management of Noxious and Exotic Weeds (FICMNEW). 2001. National Early Warning and Rapid Response System for Invasive Plants in the United States. FICMNEW, Washington, DC.

Fish and Wildlife Service (FWS). 2009. "Managing Invasive Plants: Concepts, Principles, and Practices." (http://www.fws.gov/invasives/staffTrainingModule/index.html , accessed 9/23/10)

Johnson, R.L., and B. Blossey. 2002. "Eurasian Watermilfoil." In Biological Control of Invasive Plants in the Eastern United States. FHTET-2002-04, XXX-XXX. USDA Forest Service Publication, Morgantown, WV.

Johnston, J.W., Jr. 2003. "Exotic Plant Survey at Selected Natural Areas on the Oak Ridge Reservation." Memo to Pat Parr, September 30, 2003. Under DOE Contract No. 4000025838.

Mann, L.K., P.D. Parr, L.R. Pounds, and R.L. Graham. 1996. "Protection of Biota on Nonpark Public Lands: Examples from the U.S. Department of Energy Oak Ridge Reservation." Environmental Management 20(2):208-218.

Miller, J.H. 2003. Nonnative Invasive Plants of Southern Forests, A Field Guide for Identification and Control. Southern Research Station General Technical Report, SRS-62. Asheville, NC. (http://www.invasive.org/eastern/srs/, accessed 9/27/10)

National Invasive Species Council (NISC). 2001. "Management Plan: Meeting the Invasive Species Challenge." Washington, DC.

(http://www.invasivespecies.gov/main_nav/mn_NISC_ManagementPlan.html, accessed 6/30/11)

National Invasive Species Council (NISC). 2008. 2008-2012 National Invasive Species Management Plan. Washington, DC. (http://www.fs.fed.us/ficmnew/documents/guidance/20082012 National Invasive Species Management Plan.pdf, accessed 8/26/10)

Parr, P.D., M.G. Ryon, H.D. Quarles, N.R. Giffen, M.S. Salk, and J.W. Webb. 2004. Invasive Plant Management Plan for the Oak Ridge Reservation. ORNL/TM-2004/98. Oak Ridge National Laboratory, Oak Ridge, TN. (http://www.esd.ornl.gov/facilities/nerp/invasive plant plan_2004.pdf, accessed 6/13/11) 
Plant Conservation Alliance (PCA), Alien Plant Working Group). 2009. "Kudzu."

(http://www.nps.gov/plants/alien/fact/pumo1.htm, accessed 9/22/10)

Quarles, H.D., M.S. Salk, P.D. Parr, M.G. Ryon and N.R. Giffen. 2011. Invasive Plant Management Plan for the Oak Ridge Reservation. ORNL/TM-2004/98/R1. Oak Ridge National Laboratory, Oak Ridge, TN.

Roy, W.K., J.W. Evans, and M.G. Ryon. 2001. "The Red-Headed Woodpecker and Brown-Headed Nuthatch on the Oak Ridge Reservation: Relationship to Recent Landscape Changes." Migrant 72(1): $1-12$.

Ryon, M.G., P.D. Parr, and K. Cohen. 2007. Native Grass Community Management Plan for the Oak Ridge Reservation. ORNL/TM-2006/149. Oak Ridge National Laboratory, Oak Ridge, TN.

Tennessee Exotic Pest Plant Council (TN EPPC). 2009. "Invasive Exotic Pest Plants in Tennessee," Wildland Weeds 13(1):13-16. (http://www.tnieppc.org/system/uploads/619/original/tni-eppc-plantlist-ww-w09-final-1.pdf, accessed 7/19/2010)

The Nature Conservancy (TNC). 2010. Fire Management Manual. Ed. B. Heumann. (http://www.tncfiremanual.org/about.htm, online document is revised as needed, accessed 9/23/2010)

Tu, M., C. Hurd, and J.M. Randall. 2001. Weed Control Methods Handbook. The Nature Conservancy. (http://www.invasive.org/gist/products/handbook/methods-handbook.pdf, online document is regularly revised, accessed 9/23/2010)

Van Driesche, R., B. Blossey, M. Hoodle, S. Lyon, and R. Reardon. 2002. Biological Control of Invasive Plants in the Eastern United States. FHTET-2002-04. USDA Forest Service Publication, Morgantown, WV. (http://wiki.bugwood.org/Archive:BCIPEUS, accessed 7/19/10).

Weaver, M.A., and M.E. Lyn. 2007. "Compatibility of a Biological Control Agent with Herbicides for Control of Invasive Plant Species.” Natural Areas Journal 27(3): 264-268. (http://www.bioone.org/doi/abs/10.3375/0885-

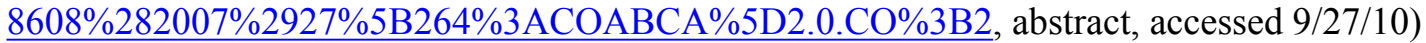

Westbrooks, R.G. 1998. Invasive Plants: Changing the Landscape of America: Fact Book. Federal Interagency Committee for the Management of Noxious and Exotic Weeds, Washington, DC. (http://digitalcommons.usu.edu/cgi/viewcontent.cgi?article=1489\&context=govdocs, accessed $6 / 13 / 11)$

Western Area Power Administration (WAPA). 1999. Integrated Vegetation Management Environmental Guidance Manual. (http:/www.wapa.gov/cso/officefun/env/pdf/vegall.pdf, accessed on April 15, 2003; not found 7/19/2010).

Western Area Power Administration (WAPA). 2007. Integrated Vegetation Management Guide and Transmission Vegetation Management Program.

Wittenberg, R., and M.J.W. Cook. 2001. Invasive Alien Species: A Toolkit of Best Prevention and Management Practices. CAB International Press, Washington, DC. 

APPENDIX A: OAK RIDGE RESERVATION NON-NATIVE, INVASIVE PLANT SPECIES LIST 



\section{APPENDIX A: OAK RIDGE RESERVATION NON-NATIVE AGGRESSIVE PLANT SPECIES LIST}

\section{RANK DEFINITIONS}

Severe Threat: Exotic plant species that possess characteristics of invasive species and spread easily into native plant communities and displace native vegetation.

Significant Threat: Exotic plant species that possess invasive qualities but are not presently considered threats to native plant communities unlike those species listed as Severe Threat.

Lesser Threat: Exotic plant species that spread in or near disturbed areas and are not presently considered a threat to native plant communities.

Alert: Exotic plant species that are known to be invasive in similar habitats to those found in Tennessee, are listed as a severe threat in adjacent states, or pose substantial management difficulties where they occur but for which more information is needed to determine their invasiveness in the state of Tennessee.

Unranked: Exotic plant species that are not ranked on the Tennessee Invasive Plant Council list (2009).

\begin{tabular}{|l|l|l|}
\hline Rank & Scientific nomenclature & Common name \\
\hline Severe & Ailanthus altissima (Mill.) Swingle & Tree of heaven \\
\hline Severe & Albizia julibrissin Durz. & Mimosa \\
\hline Significant & Allium vineale $\mathrm{L}$. & Field garlic $^{\mathrm{a}}$ \\
\hline Unranked & Amaranthus retroflexus $\mathrm{L}$. & Green amaranthus \\
\hline Unranked & Ampelopsis brevipedunculata & Porcelainberry \\
\hline Significant & Arthraxon hispidus & Hairy jointgrass \\
\hline Significant & Arundo donax & Giant reed \\
\hline Severe & Celastrus orbiculate & Oriental bittersweet \\
\hline Significant & Cirsium vulgare (Savi) Ten. & Bull thistle \\
\hline Alert & Coronilla varia L. & Crown vetch \\
\hline Severe & Dioscorea batatas & Chinese yam \\
\hline Unranked & Echinochioa crus-galli & Barnyard grass \\
\hline Severe & Elaeagnus umbellate Thunb. & Autumn olive \\
\hline Significant & Elaeagnus pungens Thunb. & \\
\hline
\end{tabular}




\begin{tabular}{|c|c|c|}
\hline Lesser & Euonymus alata (Thunb) Sieb & Burning bush \\
\hline Severe & Euonymus fortune (Turcz.) Hand.-Mazz. & Winter Creeper ${ }^{\mathrm{a}}$ \\
\hline Unranked & Festuca arundinacea Schreb. & Tall fescue \\
\hline Unranked & Festuca pratensis Huds. & Meadow fescue \\
\hline Significant & Glechoma hederacea L. & Gill-over-the-ground, ground ivy \\
\hline Alert & Kummerowia striata (Thunb.) Schindl. & Japanese clover \\
\hline Significant & Lespedeza bicolor Turcz. & Biocolor lespedeza, shrubby bushclover \\
\hline Significant & Lespedeza cuneate (Dum.-Cours.) G. Don & Sericea lespedeza $^{\mathrm{a}}$ \\
\hline Severe & Ligustrum sinense Lour. & Chinese privet $^{\mathrm{a}}$ \\
\hline Severe & Ligustrum japonicum Thunb. & Japanese privet \\
\hline Severe & Ligustrum vulgare L. & Common privet \\
\hline Severe & Lonicera japonica Thunb. & Japanese honeysuckle $^{\mathrm{a}}$ \\
\hline Significant & Lonicera maackii (Rupr.) Maxim. & Amur bush honeysuckle $^{\mathrm{a}}$ \\
\hline Alert & Lonicera morrowii A. Gray & Morrow’s bush honeysuckle \\
\hline Alert & Lonicera tatarica $\mathrm{L}$. & Tartarian honeysuckle, twinsisters \\
\hline Alert & Lonicera $x$ bella Zabel & Bush honeysuckle \\
\hline Significant & Lysimachia nummularia $\mathrm{L}$. & Moneywort, creeping Jenney \\
\hline Severe & $\begin{array}{l}\text { Lythrum salicaria } L \text {. [all varieties and } \\
\text { cultivars\} }\end{array}$ & Purple loosestrife \\
\hline Alert & Mahonia bealei (Fortune) Carriere & Oregon grape \\
\hline Significant & Mentha $x$ piperita $\mathrm{L}$. & Peppermint \\
\hline Lesser & Mentha spicata $\mathrm{L}$. & Spearmint \\
\hline Severe & Microstegium vimineum (Trin.) A. & Camus Nepalgrass, Japanese grass ${ }^{\mathrm{a}}$ \\
\hline Significant & Miscanthus sinensis & Zebragrass \\
\hline Significant & Myriophyllum spicatum L. & Eurasian water milfoil \\
\hline Unranked & Nasturtium officinale & Watercress $^{\mathrm{a}}$ \\
\hline Severe & $\begin{array}{l}\text { Paulownia tomentosa (Thunb.) Sieb. \& Succ. } \\
\text { ex Steud }\end{array}$ & Princess tree ${ }^{\mathrm{a}}$ \\
\hline
\end{tabular}




\begin{tabular}{|l|l|l|}
\hline Unranked & Poa pratenss & Kentucky bluegrass \\
\hline Unranked & Plantago major & Common plantain \\
\hline Severe & Polygonum cuspidatum Seib. \& Zucc & Japanese knotweed, Japanese bamboo \\
\hline Unranked & Polygonum hydropiper L. & Smartweed \\
\hline Unranked & Poncirus trifoliata & Trifoliate orange \\
\hline Significant & Potamogenton crispus L. & Curly pondweed \\
\hline Severe & Pueraria montana (Lour.) Merr. & Kudzu \\
\hline Alert & Pyrus calleryana & Bradford pear, Callery pear \\
\hline Severe & Rosa multiflora Thunb. & Multiflora rose \\
\hline Unranked & Rumex conglomeratus Murray & Clustered dock \\
\hline Severe & Sorghum halepense (L.) Pers. & Johnson grass ${ }^{\mathrm{a}}$ \\
\hline Unranked & Urtica dioica L. & Stinging nettle \\
\hline Significant & Verbascum thapsus L. & Common mullein \\
\hline Unranked & Veronica arvensis & Corn speedwell \\
\hline Unranked & Veronica officinalis & Common speedwell \\
\hline Unranked & Veronica serpyllifolia L. & Chinese wisteria \\
\hline Unranked & Vicia villosa & Thed speedwell \\
\hline Significant & Vinca minor L. & Wisteria sinensis \\
\hline
\end{tabular}

${ }^{a}$ Most problematic species on the ORR (Drake, Weltzin, and Parr 2002) 

APPENDIX B: SELECTED PORTIONS OF EXECUTIVE ORDER 13112 AND EXECUTIVE ORDER 13751 



\section{APPENDIX B: SELECTED PORTIONS OF EXECUTIVE ORDER 13112}

\section{EO 13112: Invasive Species}

Sec. 2. Federal Agency Duties.

(a) Each Federal agency whose actions may affect the status of invasive species shall, to the extent practicable and permitted by law,

(1) identify such actions;

(2) subject to the availability of appropriations, and within Administration budgetary limits, use relevant programs and authorities to:

(i) prevent the introduction of invasive species;

(ii) detect and respond rapidly to and control populations of such species in a cost-effective and environmentally sound manner;

(iii) monitor invasive species populations accurately and reliably;

(iv) provide for restoration of native species and habitat conditions in ecosystems that have been invaded;

(v) conduct research on invasive species and develop technologies to prevent introduction and provide for environmentally sound control of invasive species; and

(vi) promote public education on invasive species and the means to address them; and

(3) not authorize, fund, or carry out actions that it believes are likely to cause or promote the introduction or spread of invasive species in the United States or elsewhere unless, pursuant to guidelines that it has prescribed, the agency has determined and made public its determination that the benefits of such actions clearly outweigh the potential harm caused by invasive species; and that all feasible and prudent measures to minimize risk of harm will be taken in conjunction with the actions.

(b) Federal agencies shall pursue the duties set forth in this section in consultation with the Invasive Species Council, consistent with the Invasive Species Management Plan and in cooperation with stakeholders, as appropriate, and, as approved by the Department of State, when Federal agencies are working with international organizations and foreign nations. 


\section{APPENDIX B: SELECTED PORTIONS OF EXECUTIVE ORDER 13751}

\section{EO 13751: Safeguarding the nation from the Impacts of Invasive Species}

This order amends Executive Order 13112 and directs actions to continue coordinated Federal protection and control efforts related to invasive species.

Sec. 3. Federal agency duties. Section 2 of Executive Order 13112 is amended to read as follows:

"Sec. 2. Federal agency duties. (a) Each Federal agency for which that agency's actions may affect the introduction, establishment, or spread of invasive species shall, to the extent practicable and permitted by law,

(1) Identify such agency actions;

(2) Subject to the availability of appropriations, and within administrative budgetary, and jurisdictional limits, use relevant agency programs and authorities to:

(i) prevent the introduction, establishment, and spread of invasive species;

(ii) detect and respond rapidly to eradicate or control populations of invasive species in a manner that is cost-effective and minimizes human, animal, plant, and environmental health risks;

(iii) monitor invasive species populations accurately and reliably;

(iv) provide for the restoration of native species, ecosystems, and other assets that have been impacted by invasive species;

(v) conduct research on invasive species and develop and apply technologies to prevent their introduction, and provide for environmentally sound methods of eradication and control of invasive species;

(vi) promote public education and action on invasive species, their pathways, and ways to address them, with an emphasis on prevention, and early detection and rapid response;

(vii) assess and strengthen, as appropriate, policy and regulatory frameworks pertaining to the prevention, eradication, and control of invasive species and address regulatory gaps, inconsistencies, and conflicts;

(viii) coordinate with and complement similar efforts of States, territories, federally recognized American Indian tribes, Alaska Native Corporations, Native Hawaiians, local governments, nongovernmental organizations, and the private sector; and

(ix) in consultation with the Department of State and with other agencies as appropriate, coordinate with foreign governments to prevent the movement and minimize the impacts of invasive species; and

(3) refrain from authorizing, funding or implementing actions that are likely to cause or promote the introduction, establishment, or spread of invasive species in the United States unless, pursuant to guidelines that it has prescribed, the agency has determined and made public it determination that the benefits of such actions clearly outweigh the potential harm caused by invasive species; and that all feasible and prudent measures to minimize the risk of harm will be taken in conjunction with the actions.

(d) Federal agencies that are members of the Council, and Federal interagency bodies working on issues relevant to the prevention, eradication, and control of invasive species, shall provide the Council with annual information on actions taken that implement these duties and identify barriers to advancing priority actions. 
(e) To the extent practicable, Federal agencies shall also expand the use of new and existing technologies and practices; develop, share, and utilize similar metrics and standards, methodologies, and databases and, where relevant, platforms for monitoring invasive species; and facilitate the interoperability of information systems, open data, analytics, predictive modeling, and data reporting necessary to inform timely, science-based decision making.

Sec. 4. Emerging Priorities. Federal agencies that are members of the Council, and Federal interagency bodies working on issues relevant to the prevention, eradication, and control of invasive species shall take emerging priorities into consideration, including:

(b) Federal agencies shall consider the impacts of climate change when working on issues relevant to the prevention, eradication, and control of invasive species, including in research and monitoring efforts, and integrate invasive species into federal climate change coordinating frameworks and initiatives.

(c) Federal agencies shall consider opportunities to apply innovative science and technology when addressing the duties identified in section 2 of Executive Order 13112, as amended, including, but not limited to, promoting open data and data analytics; harnessing technological advances in remote sensing technologies, molecular tools, cloud computing, and predictive analytics; and using tools such as challenge prizes, citizen science, and crowdsourcing. 

APPENDIX C: ANNUAL TREATMENT SUMMARIES FOR ALL MANAGEMENT APPROACHES 



\section{APPENDIX C: ANNUAL TREATMENT SUMMARIES FOR ALL MANAGEMENT APPROACHES}

Summaries of work conducted to control invasive plants on the ORR are given below and sorted by year. Table 5 shows the number of acres of invasive plants treated each year for major treatment types.

\section{3}

The invasive plant control program for the ORR was initiated using both commercial contractors and ORNL ESD employees.

- Contractor 1: Certified Services Co. (CSC) is an industrial vegetation control contractor.

- Areas treated: Roadside vegetation, ORNL campus and ROWs, and fields surrounding deer check station for autumn olive. Treatment of the kudzu infestation at the ESD communications tower with a picloram-based, restricted-use herbicide.

- Contractor 2: Invasive Plant Control, Inc. (IPC) specializes in control of invasive plants in environmentally protected areas.

- Areas treated: Kudzu in RA8 with herbicides selected to minimize the possibility of collateral damage to nearby desirable vegetation. Treated kudzu along East Fork Poplar Creek in front of Y-12. Treated a variety of invasive plants along creeks within ORNL, along woods and roadside edges, along the Y-12 boundary fence, and within the African burial ground near ETTP.

- Environmental Sciences invasive plant management team (ESD).

- Areas treated: Hembee Marsh, Bethel Valley Road and Old Bethel Valley Road, RA8, and native grass demonstration areas. 


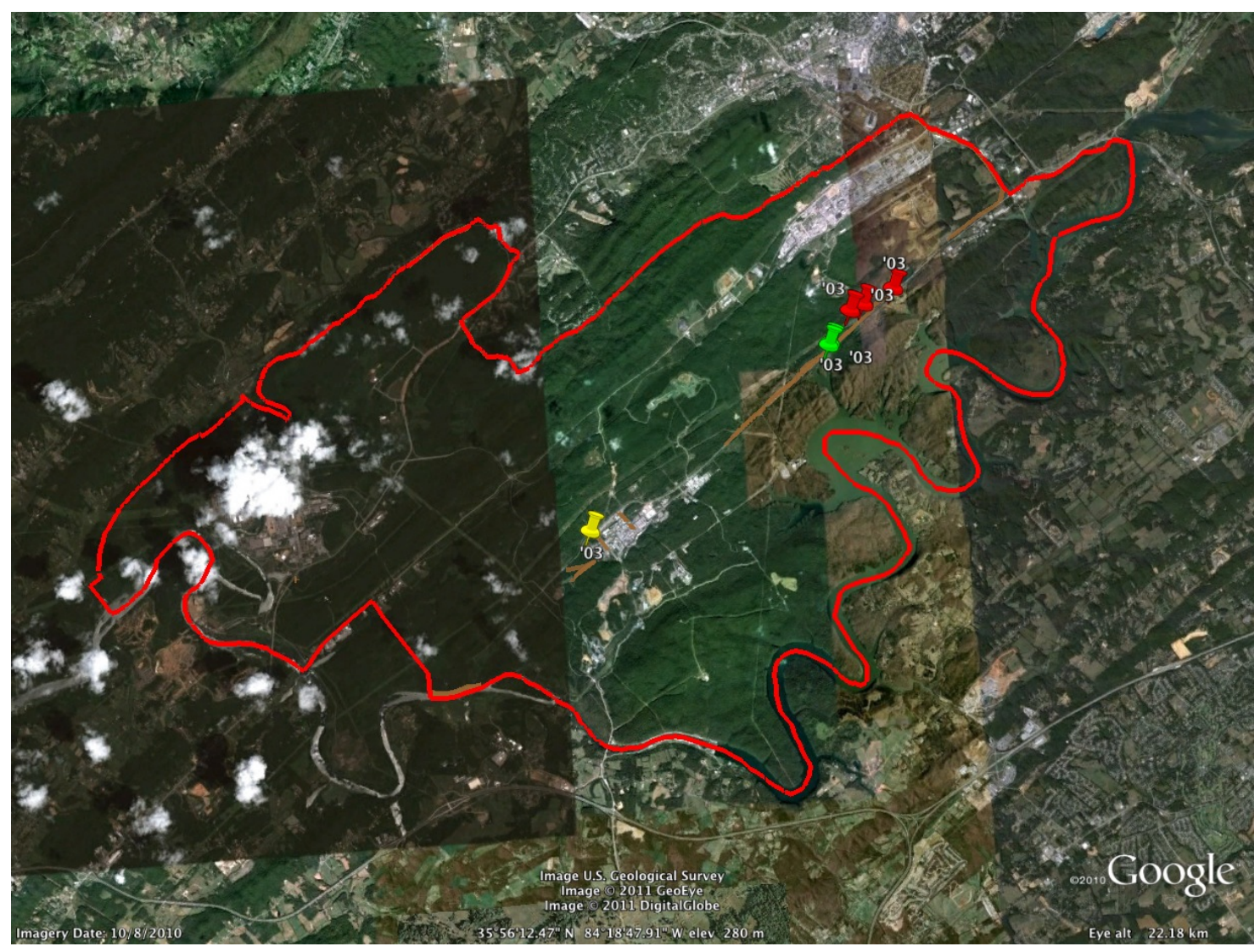

Figure C-1. Summary of treatment areas for 2003. 
- $\mathrm{CSC}$

- Areas treated: Kudzu at ESD communications tower, intersection of Oak Ridge Turnpike and Bethel Valley Road. Treated autumn olive in TVA ROW at Mount Vernon Road.

- $\mathrm{ESD}$

- Areas treated: Treated a variety of invasive plants along roadways, woods, and ROW edges, including North Boundary Trail in NA20 from Oak Hills Estates to East Fork Poplar Creek.

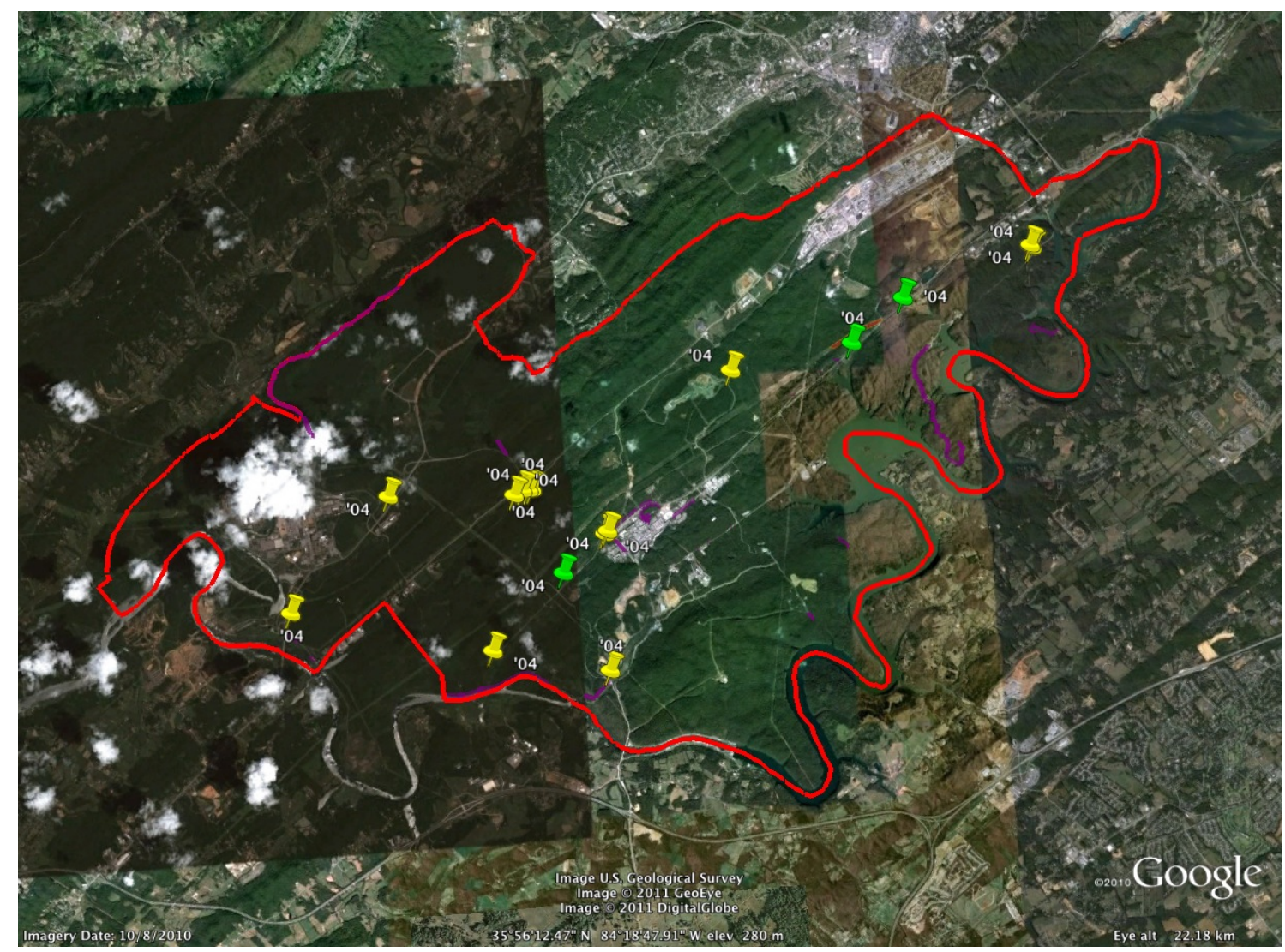

Figure C-2. Summary of treatment areas for 2004 
- $\mathrm{CSC}$

- Areas treated: Kudzu at ESD communications tower, intersection of Oak Ridge Turnpike and Bethel Valley Road.

- IPC

- Areas treated: Y-12 229 boundary fence was treated for multiple species.

- $\mathrm{ESD}$

- Areas treated: Roadside treated for multiple species. First Creek treatment, followed by planting of native grasses.

- TVA

- Areas treated: 500KV Power line ROW at Mount Vernon Road using an aerial herbicide application.

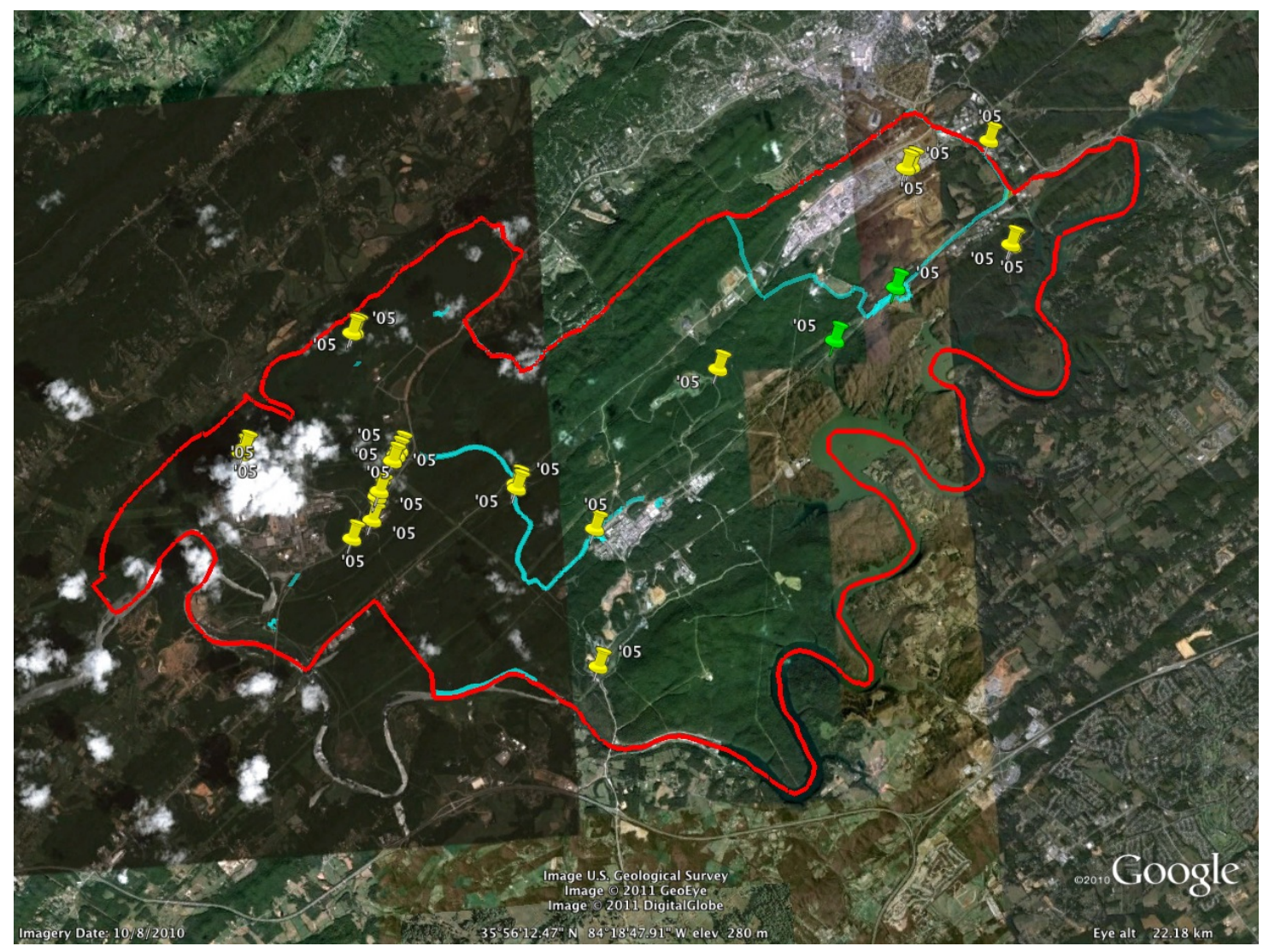

Figure C-3. Summary of treatment areas for 2005. 
- $\mathrm{CSC}$

- Areas treated: ORNL 7000 area and ORNL West End Treatment Facility were treated for kudzu.

- $\mathrm{ESD}$

- Areas treated: 13.6 miles of riparian zone were treated for multiple species. Also treated were the ORNL East Campus Pond and North Tributary 3 in the Bear Creek Valley.

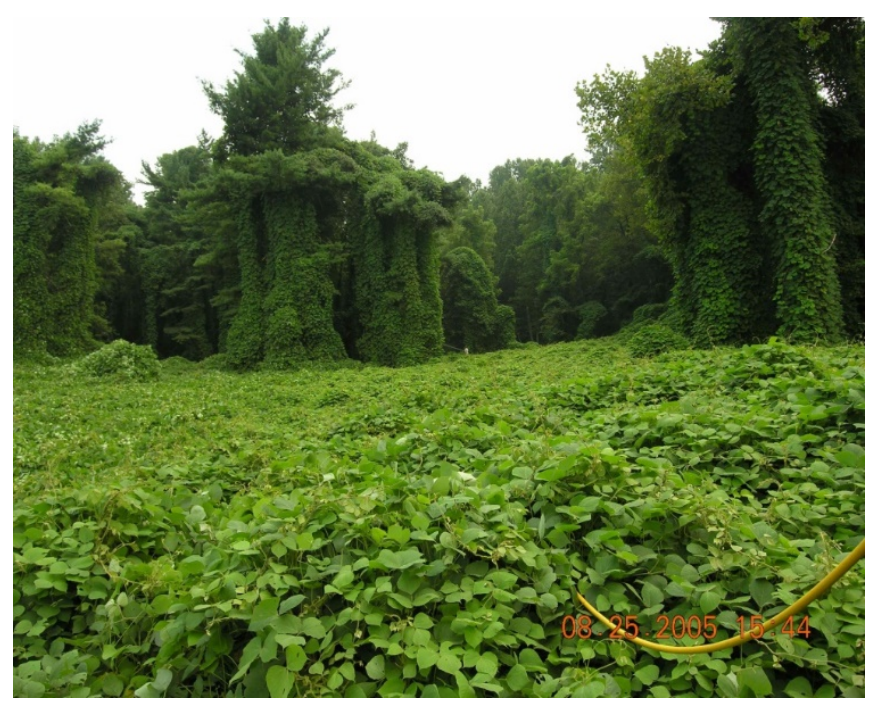

Figure C-4. A. Before kudzu treatment.

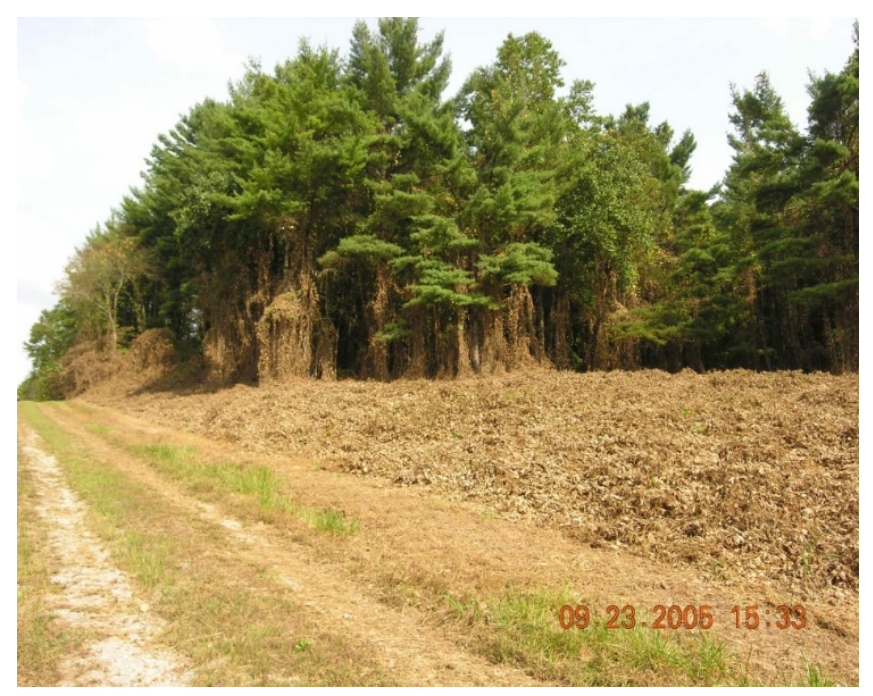

Figure C-4. B. One year after kudzu treatment.. 


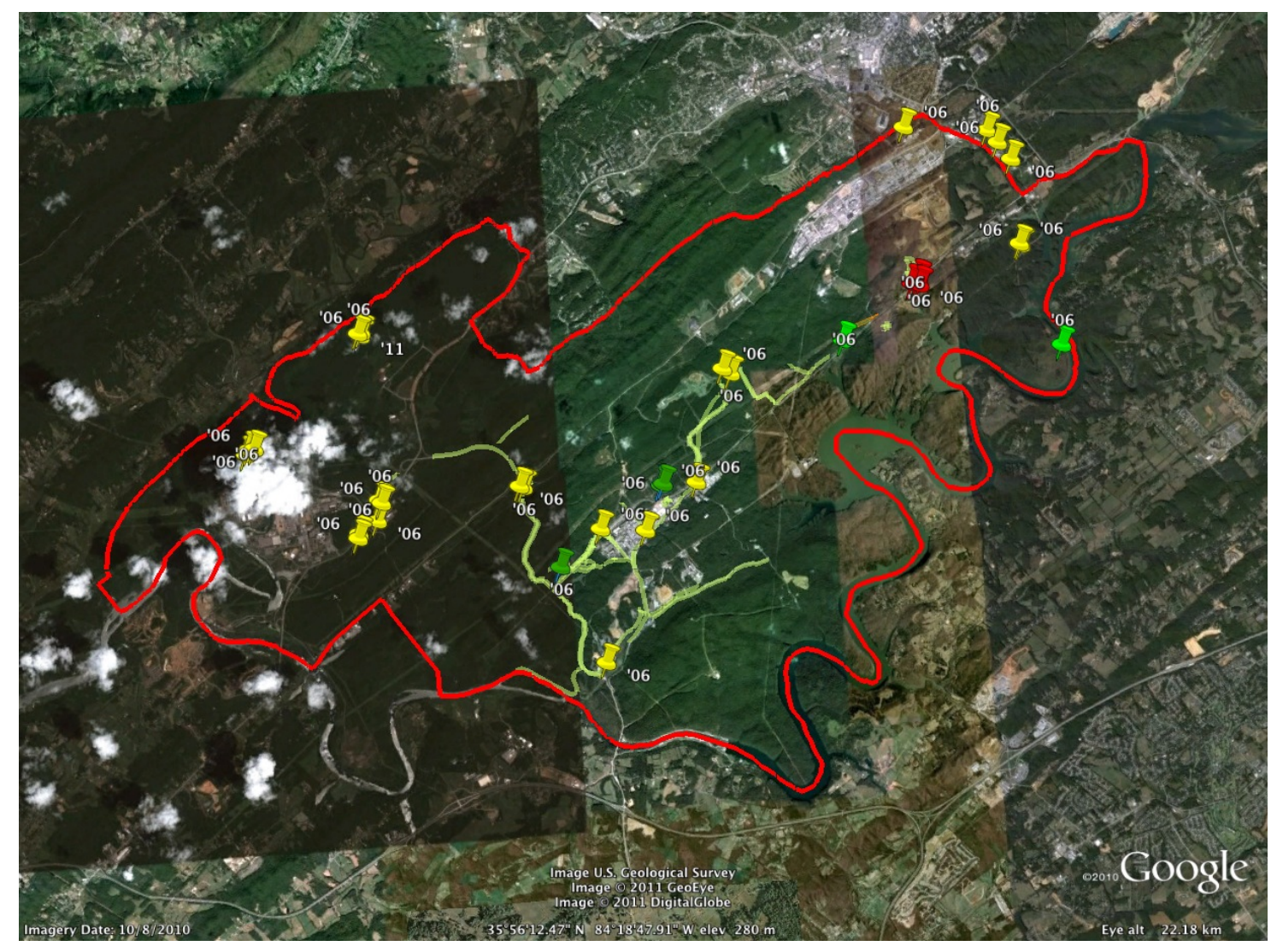

Figure C-5. Summary of treatment areas for 2006. 
- $\mathrm{CSC}$

- Areas treated: Kudzu along ETTP railroad siding and Black Oak Ridge Conservation Easement. Kudzu patches from previous years were re-treated as needed.

- $\mathrm{ESD}$

- Areas treated: Purple loosestrife was treated in the Scarboro Marsh area. Giant reed grass and zebragrass were new infestations and were treated where found. More than 52 miles of roadside was treated for multiple species.

- ORNL grounds maintenance

- Areas treated: Ailanthus altissima was treated within TVA ROWs in the Tower Shielding area.

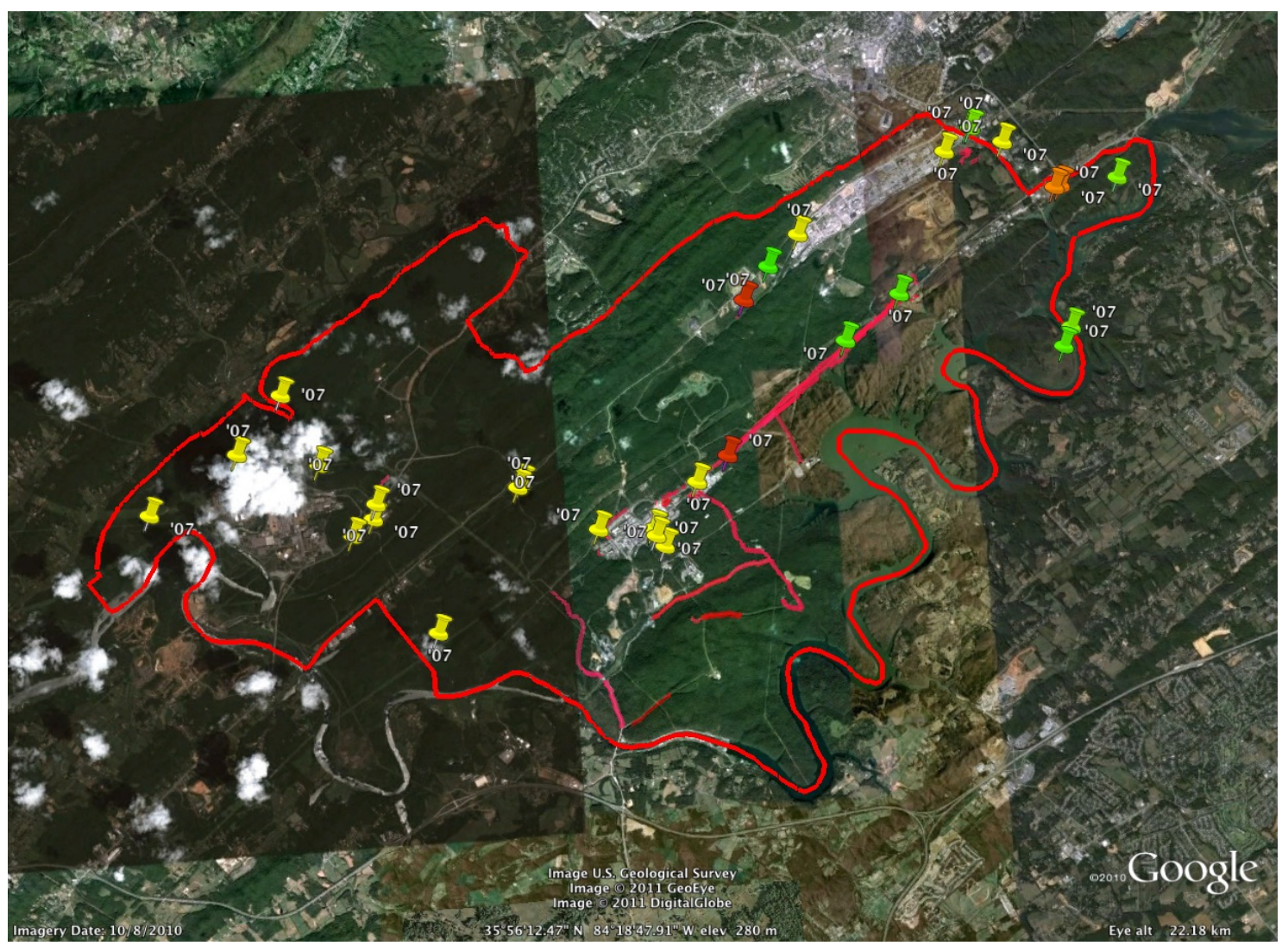

Figure C-6. Summary of treatment areas for 2007 
- $\mathrm{CSC}$

- Areas treated: Spot treatment of kudzu patches already treated. Started treatment of a new patch of kudzu located at McKinney Ridge.

- $\mathrm{ESD}$

- Areas treated: Fire roads on the ORR were treated for multiple species.

- ESD and the Tennessee Division of Forestry used prescribed burns to help control invasive species treated within native grass communities.

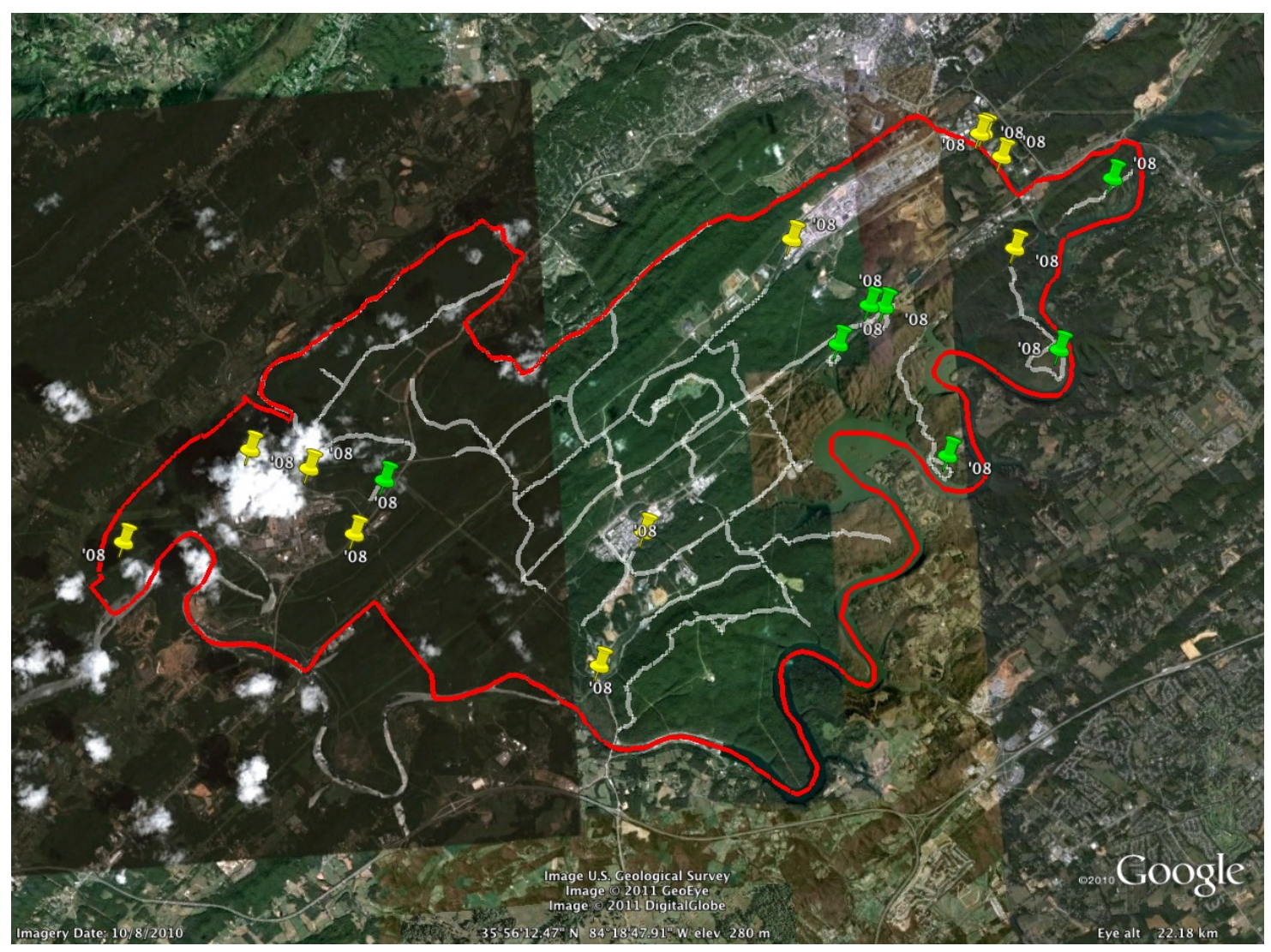

Figure C-7. Summary of treatment areas for 2008 
- $\mathrm{CSC}$

- Areas treated: Follow-up treatment of previously treated kudzu patches. Began treatment of kudzu on Gallaher Bend. Also treated autumn olive along Bethel Valley Road and Old Bethel Valley Road. Princess tree treatment on the Y-12 campus.

- $\quad \mathrm{ESD}$

- Areas treated: ORNL East Campus Pond, ETTP P1 Pond, and other riparian areas at ORNL, and along White Wing Road.

- Contractor 3: Progressive Solutions, Inc. (PS). Large number of on-the-ground workers with backpack sprayers and cut-surface application equipment are used to sweep through areas, locating and controlling all invasive species present.

- Areas treated: Treatment started on Freels Bend, a 442-acre area of mixed field and early successional field.

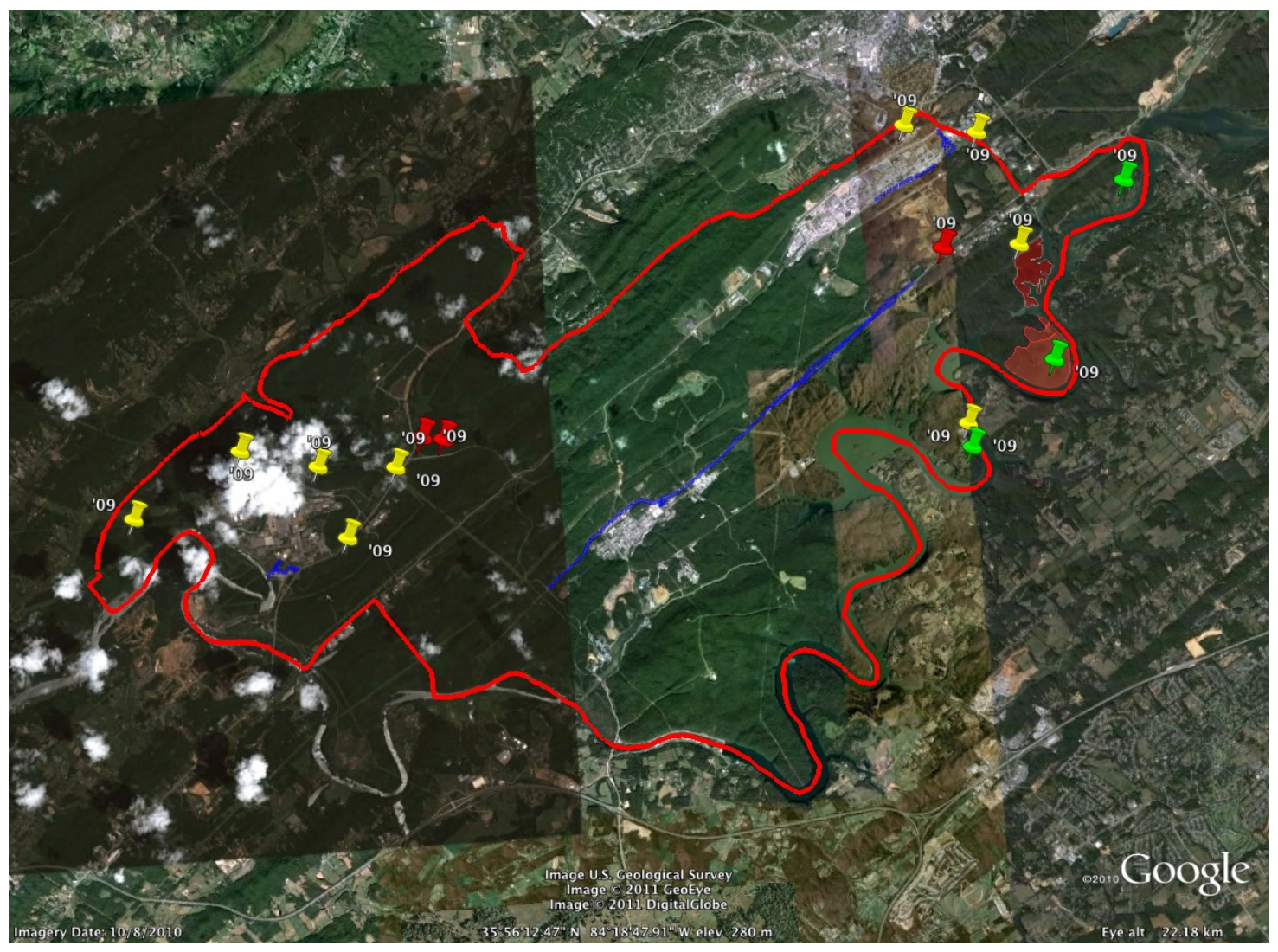

Figure C-8. Summary of treatment areas for 2009. 


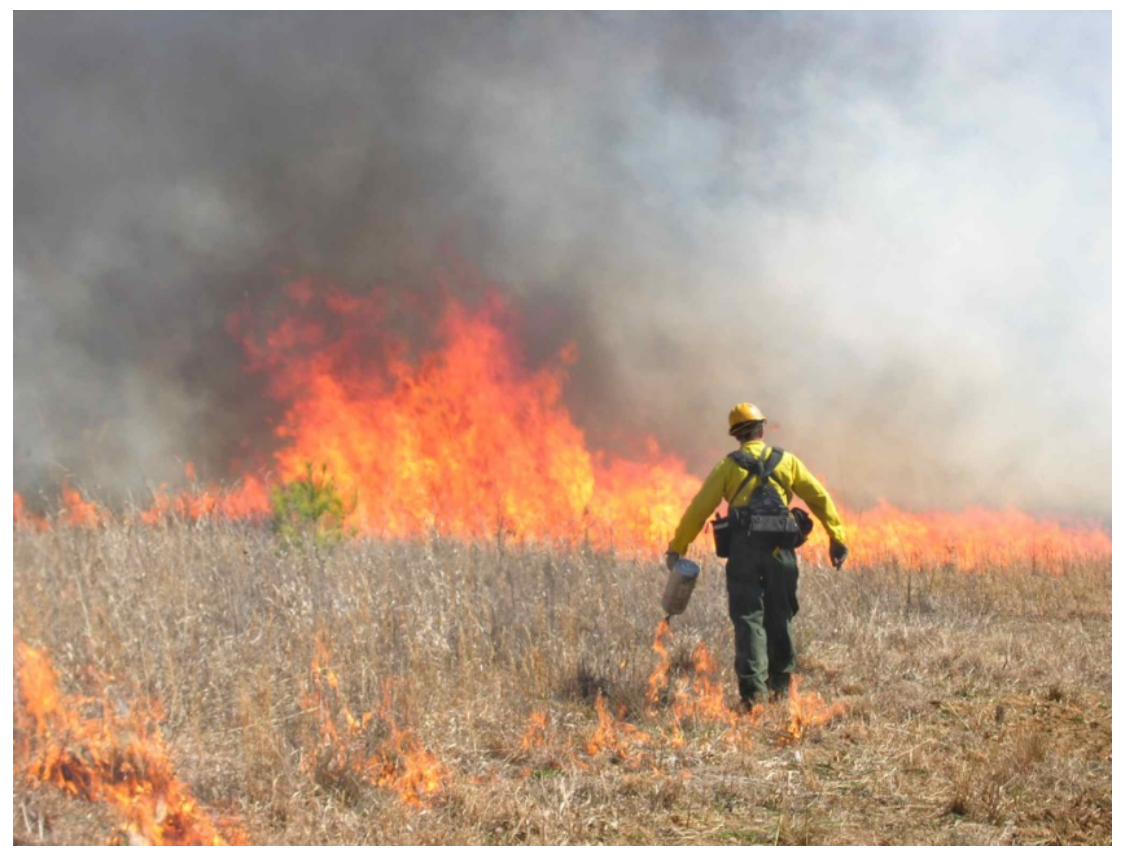

Figure C-9. Control of invasive plants within a native grass community is aided by controlled burning 
- $\mathrm{CSC}$

- Areas treated: Kudzu at Gallaher Bend and previously treated kudzu patches, including the patrol road at ETTP and the ETTP railroad siding. In addition, CSC controlled invasive plants along East Fork Poplar Creek within Y-12.

- PS

- Areas treated: Freels Bend treatment areas were expanded. Autumn olive treatments were conducted along Bethel Valley Road and in fields surrounding the TWRA deer check station. PS treated 777 new acres.

- $\mathrm{ESD}$

- Areas treated: ETTP P1 Pond and native grass restoration areas were treated.

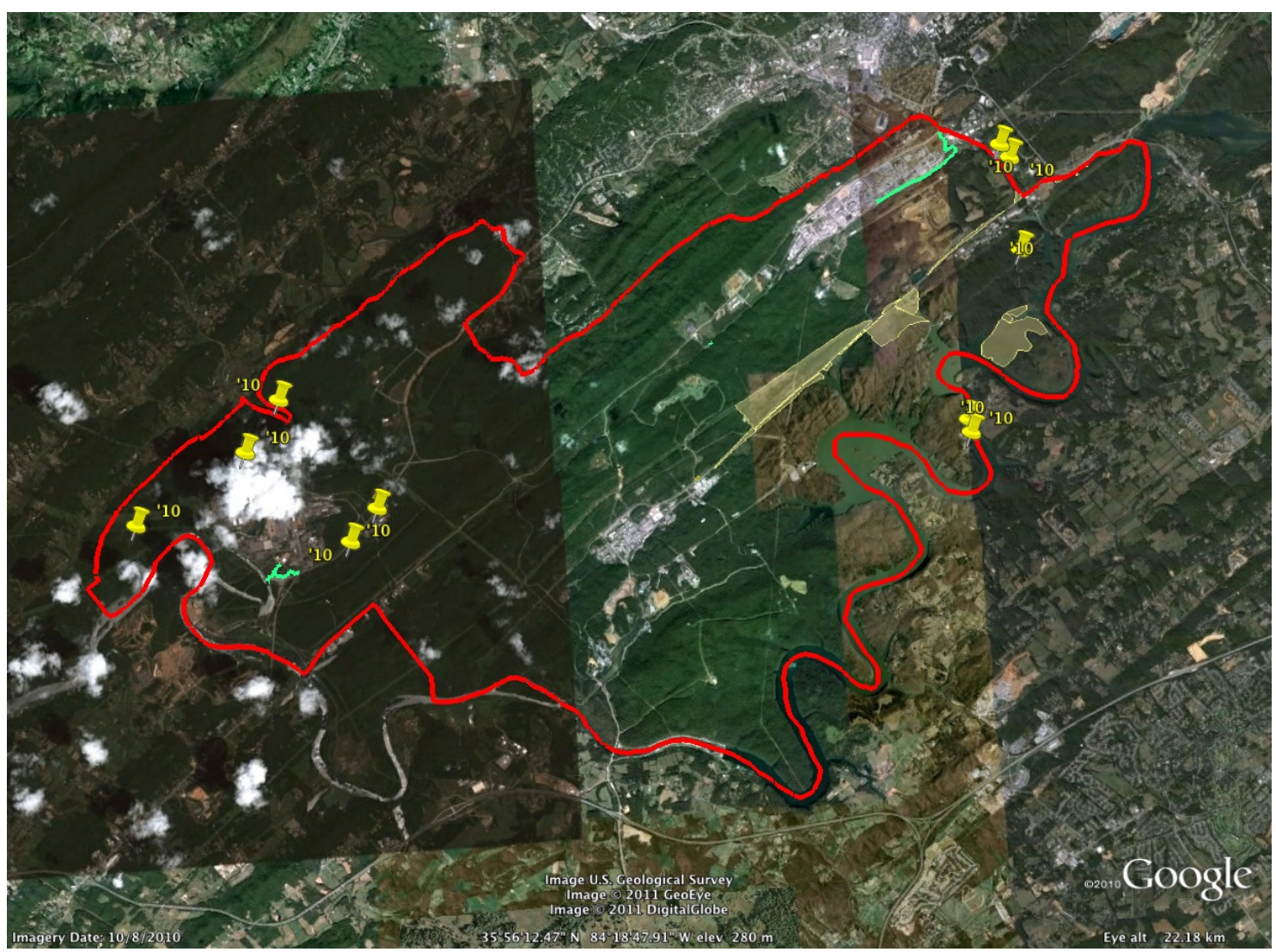

Figure C-10. Summary of treatment areas for 2010. 
- $\mathrm{CSC}$

- Areas treated: Kudzu treatment at Gallaher Bend was expanded, and previously treated kudzu patches were checked and re-treated as necessary. More new patches of kudzu near the City of Oak Ridge Water Plant on top of Pine Ridge were treated. Areas within the Y-12 campus were treated for princess trees and other invasive plants, including around Lake Reality and East Fork Poplar Creek.

- $\quad$ PS

- Areas treated: Work at Freels Bend continued, with 200 acres successfully treated. Bethel Valley Road and Old Bethel Valley Road, including the north side of Bethel Valley Road through the ORNL campus, were treated for multiple species. Native Grass fields near the east guard portal DOE land - extending from the south side of Bethel Valley Road to the top of Haw Ridge from Scarboro Road to the Native Grass fields - were treated for multiple species of invasive plants.

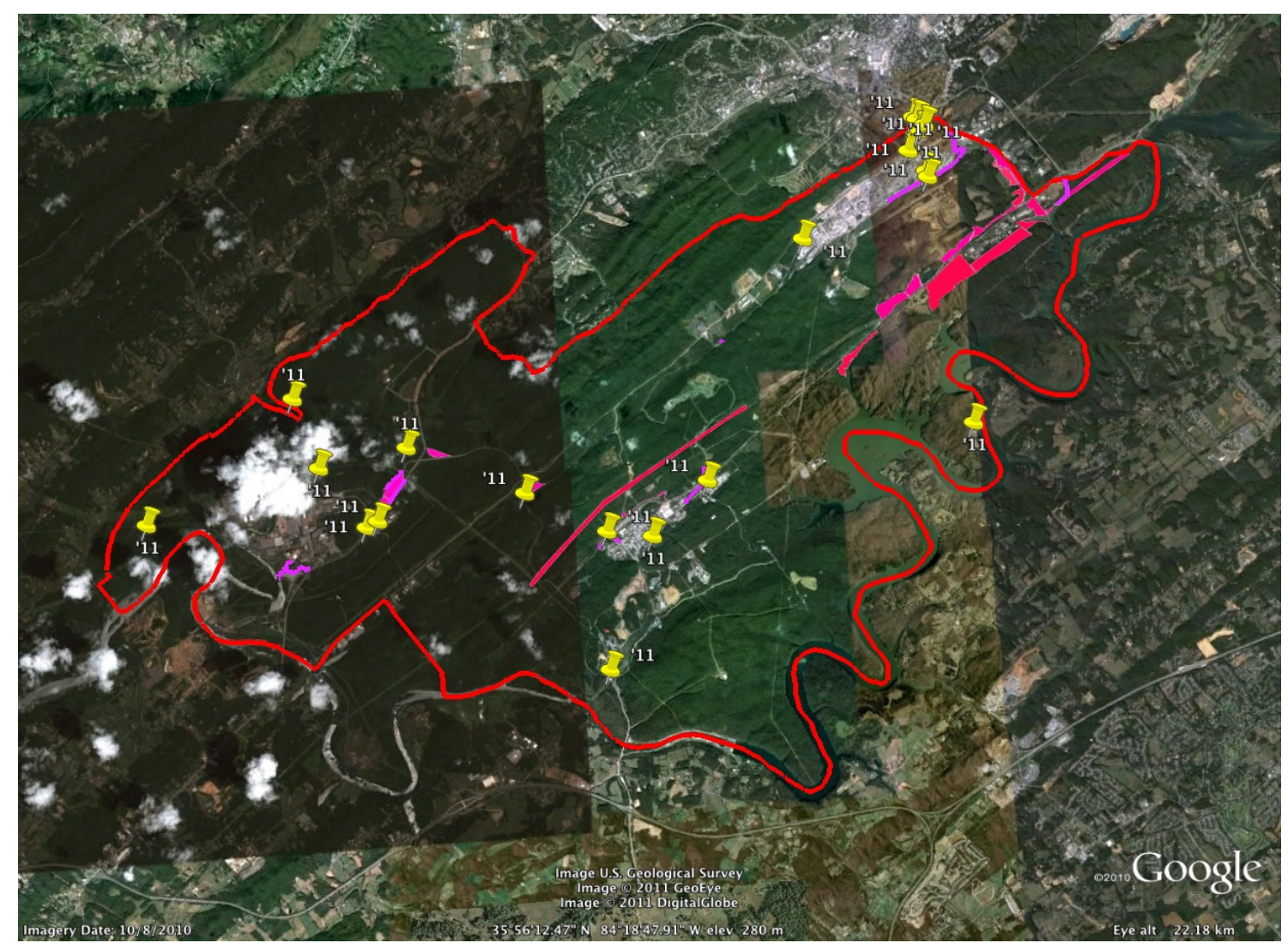

Figure C-11. Summary of treatment areas for 2011. 
- $\mathrm{CSC}$

- Areas treated: Kudzu treatments were continued at all areas previously treated except Gallaher Bend. Work to remove invasive plants within the Y-12 campus was continued as well. Kudzu patches along ETTP Perimeter Road were added to CSC's work.

- PS

- Areas treated: Multiple plant treatments were conducted in several large areas across the ORR. These areas included:

- Bearden Creek Peninsula, Jones Island Road and adjacent fields, Solway Creek inlet, and Gallaher Bend.

- $\mathrm{ESD}$

- Areas treated: Multiple species were treated along Spallation Drive and nearby fire roads, along with a wooded area west of First Creek and the First Creek native grass field restoration area. Several prescribed burns were conducted to remove dead kudzu in previously treated areas. White pine tree and native grass were planted around Gallaher Bend.

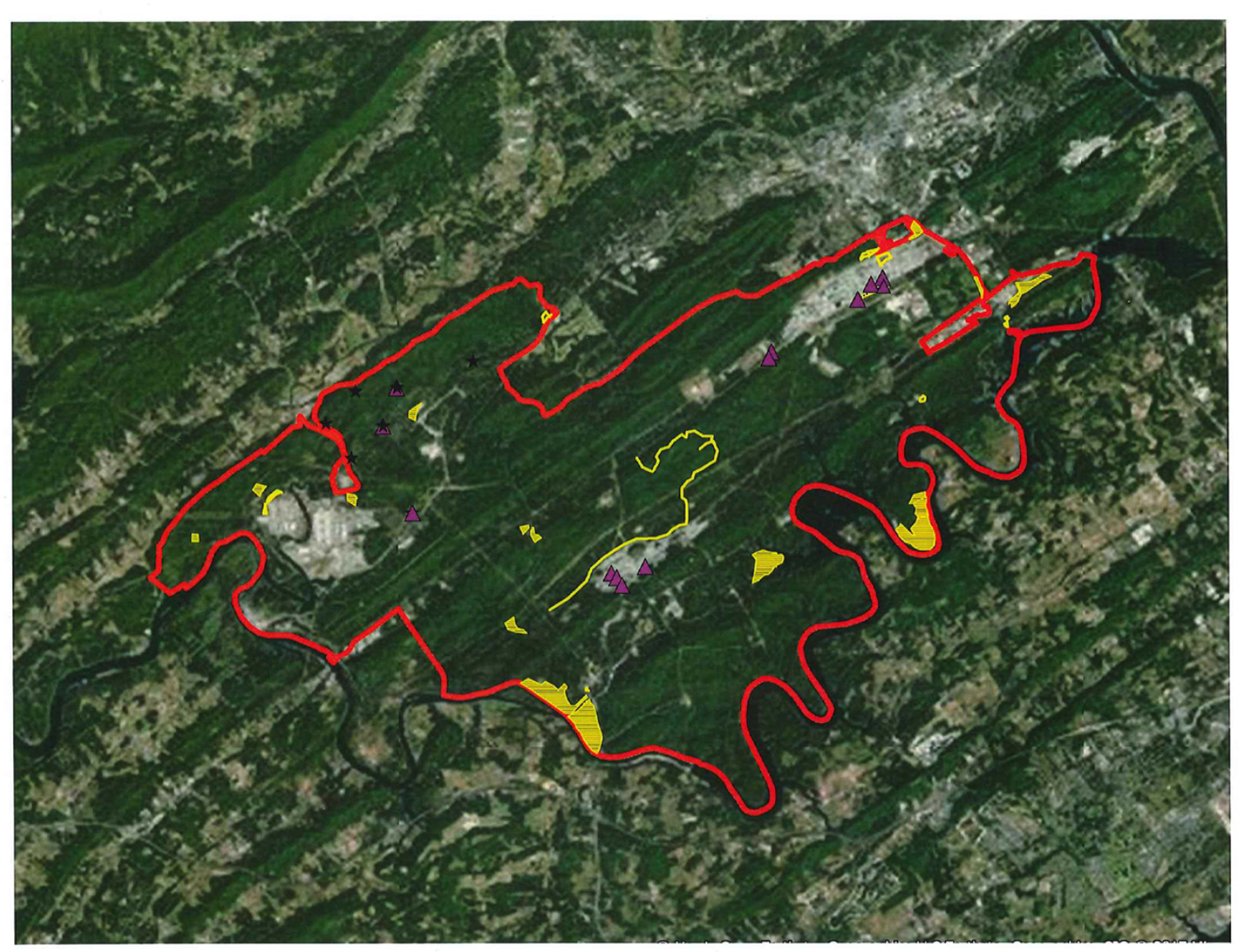

Figure C-12. Summary of treatment areas for 2012. 
- $\mathrm{CSC}$

- Areas treated: Kudzu on both ridge sides facing Y-12, Hickory Creek Bend kudzu patch, Y12 coal ash pond dam and slough, intersection of Bear Creek Road and Highway 95, Clear Springs Road kudzu patch, kudzu and other invasive plants near Wheat Church and vista, ETTP Perimeter Road, ORNL Haw Ridge steam line ROW, kudzu at the Central Training Facility and several other areas. Multiple invasive plants were treated near Jones Island Road and the 0800 fields.

- PS

- Areas Treated: Roadsides plus $50 \mathrm{ft}$. into the woods on both sides of Pumphouse Road, Solway Bend Road, Freels Bend Road, Bull Bluff Road, and the entire Gallaher Bend greenway were treated for multiple species. Around 202 acres of Freels Bend fields were treated for multiple invasive plant species.

- $\mathrm{ESD}$

- Areas treated: ORNL coal yard field was treated for invasive plants and then seeded with native grasses and planted with native shrubs and trees to create a riparian zone along the intermittent tributary to White Oak Creek. Display mitigation areas at First Creek and HTML were treated for all invasive plants. Bethel Valley Road was treated for invasive plants on both sides of the road from Highway 95 to Spallation Drive. 


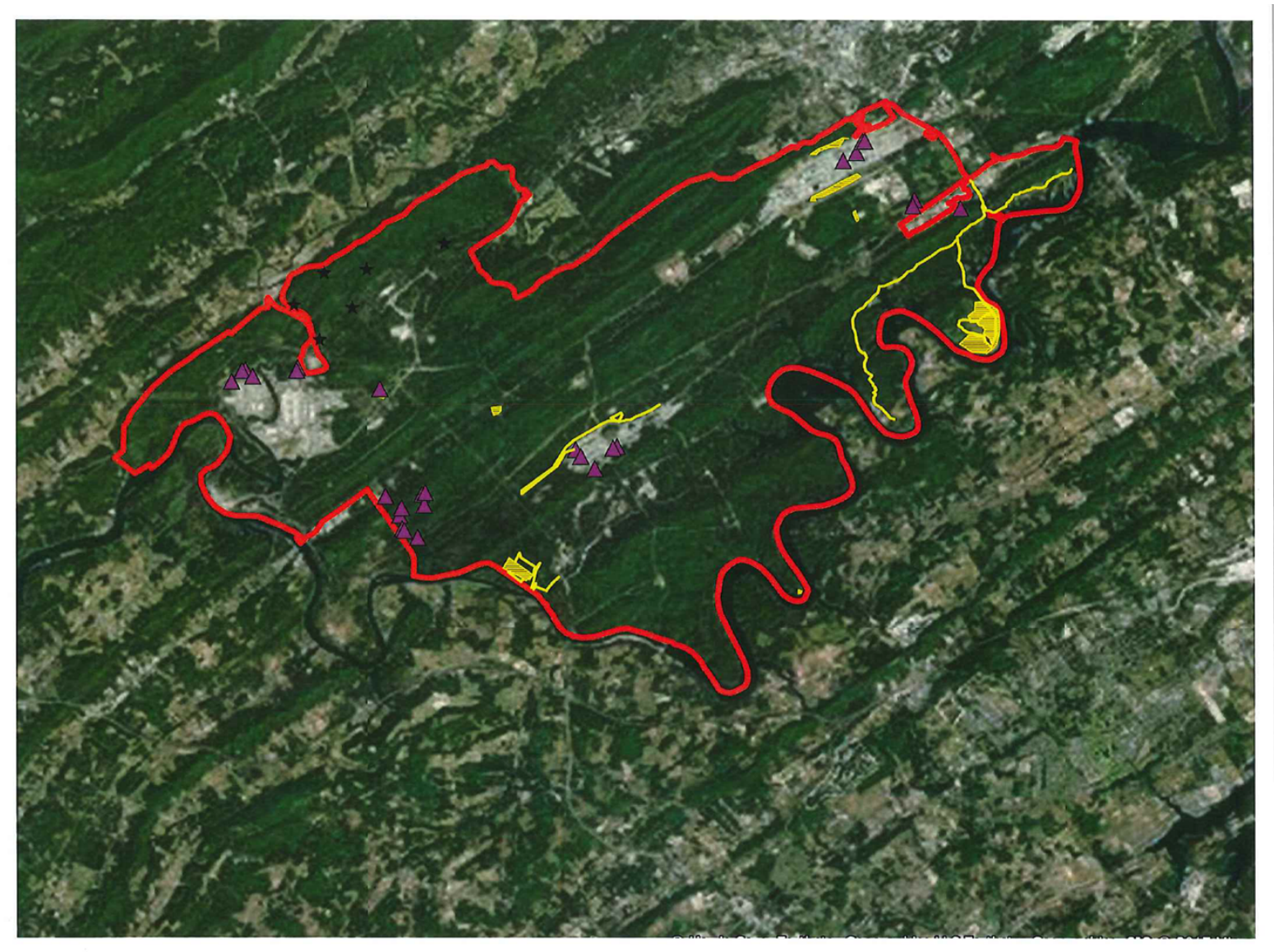

Figure C-13. Summary of treatment areas for 2013. 
- $\mathrm{CSC}$

- Areas treated: Maintenance treatment of previously treated areas to control kudzu and other invasive plants.

- PS

- Areas Treated: Treatment of kudzu within RA8/Raccoon Creek Barren. Bearden Creek was re-treated for wisteria. Grassy Creek Road was treated for kudzu. Hickory Creek peninsula, West Borrow area, Walker Branch Cove, roadside along Scarboro Road from the Y-12 boundary with the City of Oak Ridge to Bethel Valley Road. Bethel Valley Road on both sides from Scarboro Road to the ORNL campus, several hundred acres around Freels Bend, and parts of Bear Creek Road were all treated for multiple species.

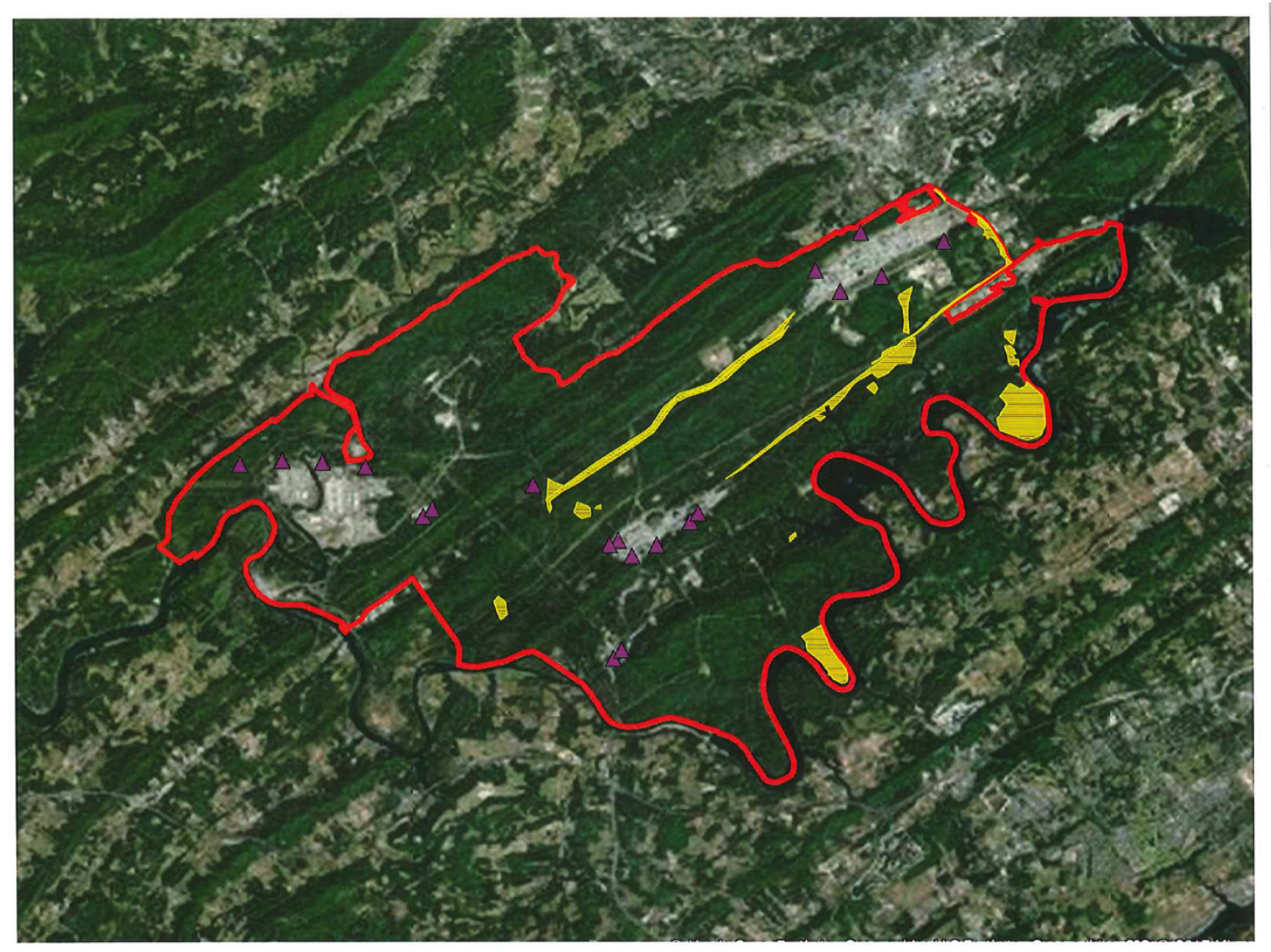

Figure C-14. Summary of treatment areas for 2014. 
- $\mathrm{CSC}$

- Areas treated: Maintenance treatment of previously treated areas to control kudzu and other invasive plants.

- PS

- Areas treated: Grassy Creek Road was treated for kudzu. Bearden Creek treated for wisteria, kudzu patch on Bull Bluff Road at Freels Bend, ED-1 kudzu patches, kudzu at the West End guard shack and Highway 95, Pumphouse Road and the Scarboro Creek marsh riparian zones, Bear Creek riparian zone, Hickory Creek Bend, Beaver Pond area at Bear Creek and Highway 95, and Walker Branch Cove were treated for kudzu.

- IPC

- Areas treated: Gallaher Bend kudzu patch was treated around forest edges, ORNL utility ROW with endangered plants (pink lady's slipper), and TVA ROWs with endangered plants were treated for multiple invasive plant species.

- ESD

- Areas treated: First Creek native grass area was treated for multiple invasive species, as were HTML riparian restoration area, and the north side of Bethel Valley Road from SNS Road to Highway 95.

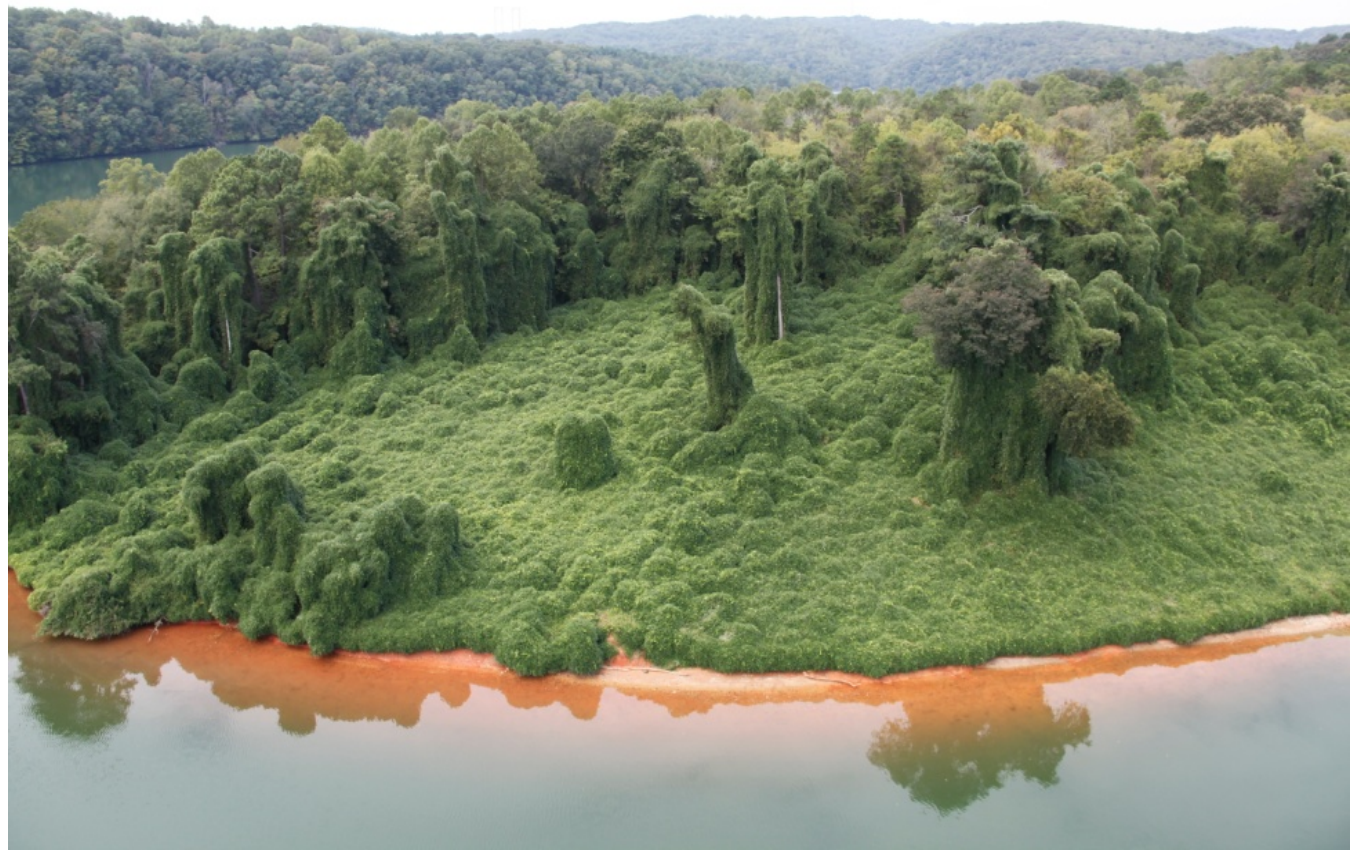

Figure C-15. Hickory Creek Bend kudzu in 2013 before treatment. 


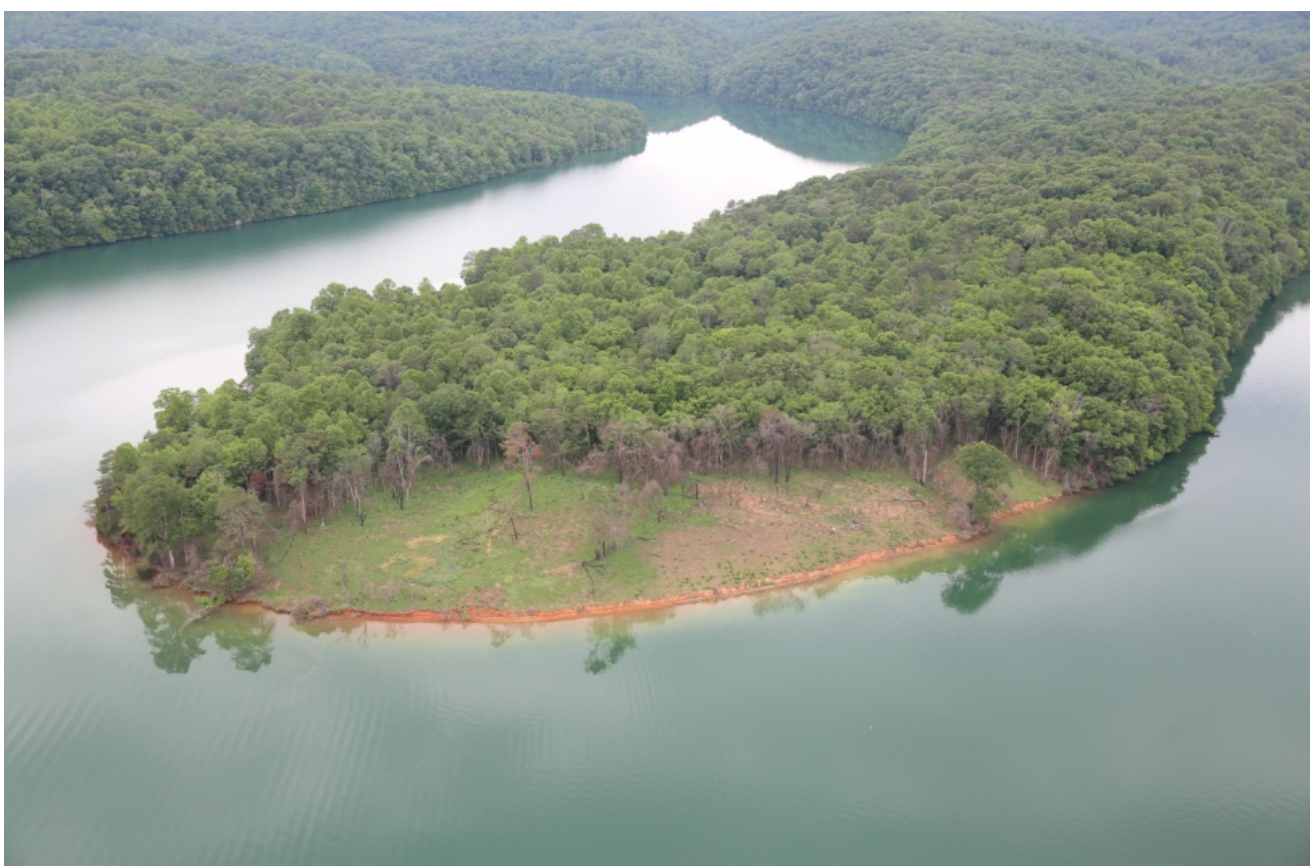

Figure C-16. Hickory Creek Bend after kudzu treatment and prescribed fire.

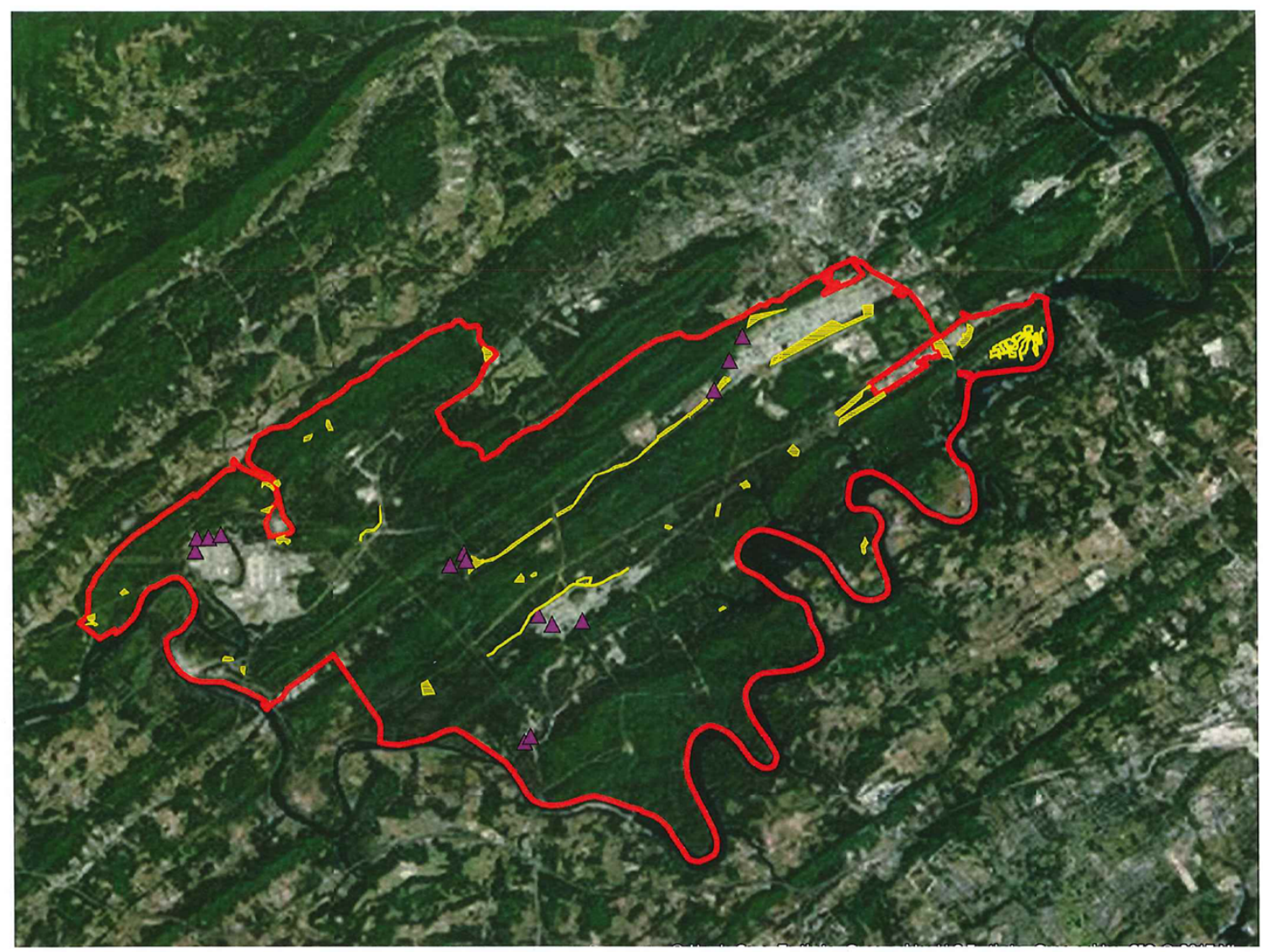

Figure C-17. Summary of treatment areas for 2015.

C-18 
- $\mathrm{CSC}$

- Areas treated: ORR boundary fence from the Y-12 229 boundary fence to Highway 95, ORR boundary fence from Highway 95 at the West End guard shack to Poplar Creek greenway, ORR boundary fence from Blair Road to the Clinch River, Black Oak Ridge kudzu patches, invasive plants surrounding Y-12 Biology Complex buildings, vegetation around gravel path and diversion channel near Lake Reality at Y-12, and areas previously treated throughout the ORR.

- PS

- Areas treated: Sludge fields at Y-12, Scarboro Creek Marsh, TVA ROW at Mount Vernon Road, intersection of Highway 95 and Bear Creek Road, Bethel Valley Road from Old Bethel Valley Road to SNS Road, Gallaher Bend former kudzu area, both sides of Bethel Valley Road-from First Street to Highway 95.

- Contractor 4: NaturChem

- Areas treated: Gallaher Bend fields and Freels Bend fields were treated with herbicide spray and mowed with a bush-hog.

- ESD

- Areas treated: Park City Road, Old Bethel Valley Road, Hawk's Nest Road, White Oak Creek riparian zone from SNS Road to Southside Road on the ORNL campus, EGCR Access Road, Robotics and Clinch River Cabin grounds, HFIR Access Road, lower field of TWRA deer check station, First Creek riparian zone, HTML riparian zone, and many other areas. 


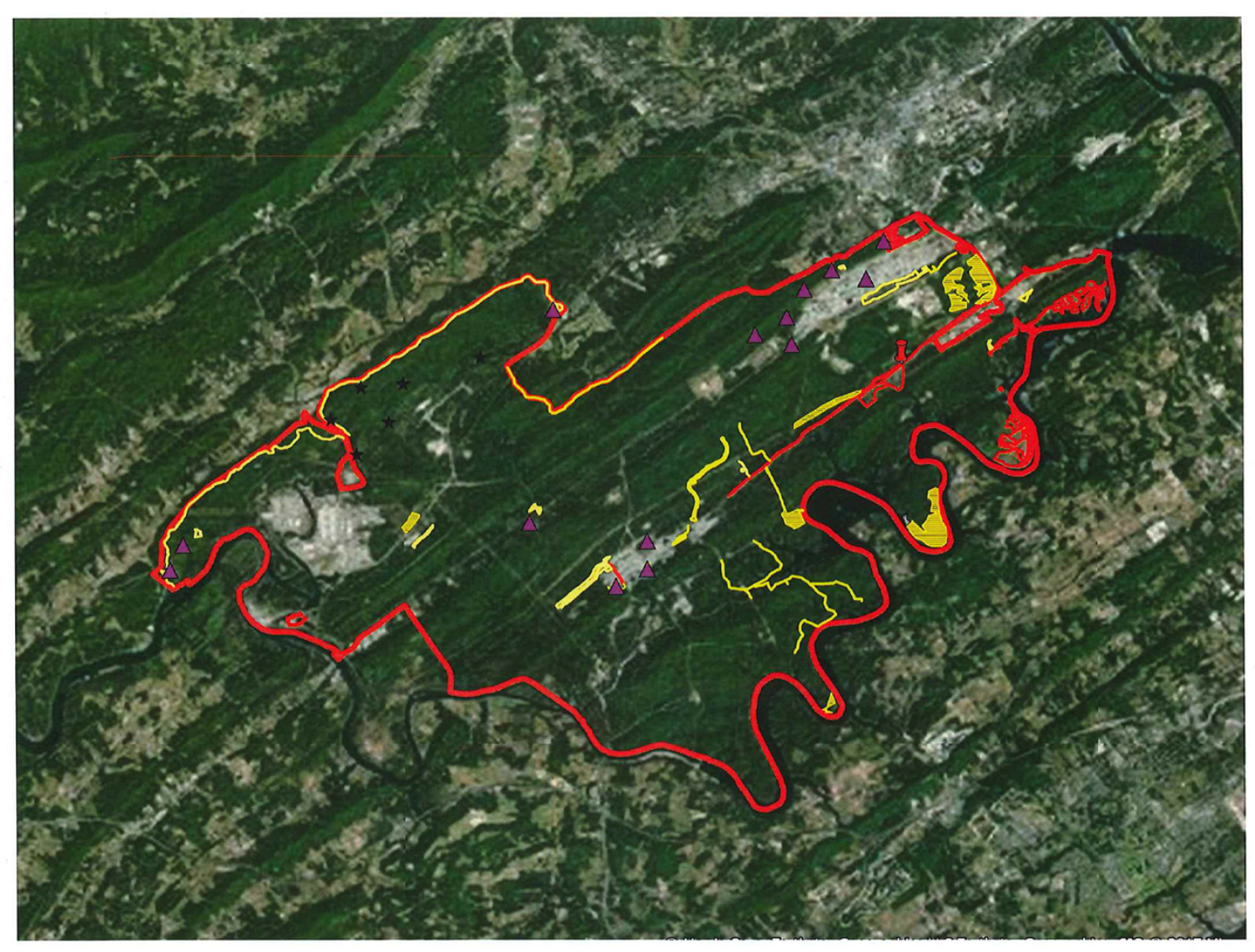

Figure C-18. Summary of treatment areas for 2016. 